\title{
Caracterização do grupo Edessa rufomarginata e descrição de sete novas espécies (Heteroptera, Pentatomidae, Edessinae) ${ }^{1}$
}

\author{
Eduardo J. Ely e Silva², José A. M. Fernandes ${ }^{3} \&$ Jocélia Grazia $^{2}$
}

1. Contribuição no 493 do Departamento de Zoologia, Universidade Federal do Rio Grande do Sul (UFRGS).

2. Departamento de Zoologia, Instituto de Biociências, UFRGS, Av. Bento Gonçalves, 9500, Bloco IV, Prédio 43435, $91501-970$ Porto Alegre, RS, Brasil.

3. Departamento de Biologia, Centro de Ciências Biológicas, UFPA, Rua Augusto Corrêa nº1, Guamá, 66075-110 Belém, PA, Brasil.

\begin{abstract}
Caracterization of the group Edessa rufomarginata and description of seven new species (Heteroptera, Pentatomidae, Edessinae). The Edessa group rufomarginata is proposed to include E. rufomarginata (De Geer, 1773 ), E. marginalis (Dallas, 1851), E. albomarginata (Stål, 1855), E. abdominalis Erichson, 1848, E. corallipes Erichson, 1848, E. aulacosterna Stål, 1872, E. ovalis Stål, 1872, and E. nigropunctata Berg, 1884. Seven new species are described in this group, six from Brazil and one from Argentina: E. brasiliensis sp. nov., E. castaneolineata sp. nov., E. cerradensis sp. nov., E. chapadensis sp. nov., E. luteovenulata sp. nov., E. rufodorsata sp. nov. (Argentina) and E. virididorsata sp. nov. These species are known from Venezuela, Suriname, Guyana, Brazil, Paraguay and Argentina.
\end{abstract}

KEYWORDS. Pentatomidae, Edessinae, Edessa, new species, taxonomy.

RESUMO. Neste trabalho é proposto o grupo Edessa rufomarginata, que inclui E. rufomarginata (De Geer, 1773), E. marginalis (Dallas, 1851), E. albomarginata (Stål, 1855), E. abdominalis Erichson, 1848, E. corallipes Erichson, 1848, E. aulacosterna Stål, 1872, E. ovalis Stål, 1872 e E. nigropunctata Berg, 1884. São descritas sete novas espécies pertencentes ao grupo, seis do Brasil e uma da Argentina: E. brasiliensis sp. nov., E. castaneolineata sp. nov., E. cerradensis sp. nov., E. chapadensis sp. nov., E. luteovenulata sp. nov., E. rufodorsata sp. nov. (Argentina) e E. virididorsata sp. nov. As espécies deste grupo ocorrem na Venezuela, Suriname, Guiana, Brasil, Paraguai e Argentina.

PALAVRAS-CHAVE. Pentatomidae, Edessinae, Edessa, novas espécies, taxonomia.

O gênero Edessa, proposto por FABRICIUS (1803), é o maior de Pentatomidae, com cerca de 260 espécies descritas até o momento. Devido à grande quantidade de espécies já conhecidas, além daquelas ainda não descritas (cerca de 300, J. A. M. Fernandes, comun. pess.), tornase impraticável revisar todo o gênero de uma única vez.

Como forma de resolver o problema, FERNANDES \& VAN Doesburg (2000a) propuseram revisar o gênero Edessa, dividindo-o em pequenos grupos de espécies com características morfológicas semelhantes, especialmente na morfologia da genitália. Até o momento, já foram descritos quatro grupos de espécies.

O grupo Edessa dolicocera (FERNANDES \& VAN Doesburg, 2000a) possui três espécies; corpo elíptico; bifurcação anterior do processo metasternal com os ápices decliventes; ângulos umerais extremamente desenvolvidos e afilados; parâmeros dentiformes.

As três espécies do grupo Edessa beckeri (Fernandes \& VAN Doesburg, 2000b) apresentam corpo oblongo; ângulos umerais não desenvolvidos; pigóforo com abertura posterior e bordo dorsal com $1+1$ cicatrizes próximas dos ângulos póstero-laterais; parâmeros dentiformes; décimo segmento com a face posterior truncada e pilosa.

O grupo Edessa cervus (Fernandes \& VAN Doesburg, 2000c) reúne seis espécies e caracteriza-se por apresentar corpo triangular, ângulos umerais extremamente desenvolvidos, com ápices intumescidos, bifurcados e truncados; processos da taça genital comprimidos lateralmente, parâmeros com dois lobos digitiformes, sendo o lobo anterior inflado; décimo segmento com constrição posterior.

O grupo Edessa collaris (FERnANDEs et al., 2001) reúne quatro espécies com o corpo triangular; ângulos umerais agudos, não-desenvolvidos; bifurcação anterior do processo metasternal com ápices evanescentes; pigóforo com abertura dorso-posterior; bordo ventral do pigóforo com reentrância acentuada; parâmeros simples, perpendiculares à taça genital; décimo segmento perpendicular ao plano sagital do pigóforo, com lobo posterior inflado e pêlos longos.

Neste trabalho é descrito o grupo Edessa rufomarginata. Este grupo é formado por oito espécies conhecidas: Edessa rufomarginata (De Geer, 1773), E. marginalis (Dallas, 1851), E. albomarginata (Stål, 1855), E. abdominalis Erichson, 1848, E. corallipes Erichson, 1848, E. aulacosterna Stål, 1872, E. ovalis Stål, 1872, E. nigropunctata Berg, 1884 e por sete novas, que são aqui descritas.

\section{MATERIAL E MÉTODOS}

Foram examinados exemplares pertencentes às seguintes coleções: Carnegie Museum of Natural History, Pittsburg, EUA (CMNH); Departamento de Zoologia da Universidade Estadual de Campinas, Campinas, SP, Brasil (ZUEC); Departamento de Zoologia, Universidade Federal do Rio Grande do Sul, Porto Alegre, RS, Brasil (UFRG); Facultad de Ciencias Naturales y Museo, División de Entomologia, Universidad Nacional de La 
Plata, La Plata, Argentina (MLPA); Museo Argentino de Ciencias Naturales "Bernardino Rivadavia", Buenos Aires, Argentina (MACN); Museo del Instituto de Zoologia Agrícola, Maracay, Venezuela (MIZA); Museu Nacional, Universidade Federal do Rio de Janeiro, Rio de Janeiro, RJ, Brasil (MNRJ); Museu Paraense Emílio Goeldi, Belém, PA, Brasil (MPEG); Museum National d'Historie Naturelle, Paris, França (MNHN); Museum für Naturkunde, Berlim, Alemanha (ZMHB); Museu de Zoologia, Universidade de São Paulo, São Paulo, SP, Brasil (MZSP); Nationaal Natuurhistorische Museum, Leiden, Holanda (RMNH); Naturhistorisches Museum Wien, Viena, Áustria (NHMW); The Natural History Museum, Londres, Inglaterra (BMNH); Universidad Nacional de Tucumán, Fundación y Instituto Miguel Lillo, San Miguel de Tucumán, Argentina (IMLA); Zoological Museum, University of Copenhagen, Copenhagen, Dinamarca (ZMUC); Coleção particular de D. Thomas (DCT); California Academy of Sciences, São Francisco, California, EUA (CAS); Museu de Ciências Naturais, Fundação Zoobotânica do Rio Grande do Sul, Porto Alegre, RS, Brasil (MCNZ).

A terminologia adotada para as peças genitais segue Dupuis (1970) e as medidas são apresentadas em milímetros.

Para as ilustrações de Edessa aulacosterna, E. ovalis Stål, 1872 e três das espécies novas, foi utilizada a técnica de grafite, devido ao número reduzido de exemplares para dissecação da genitália masculina e extração dos parâmeros e dos processos da taça genital. Deste modo, com a técnica empregada se buscou melhor representação do material estudado.

\section{Caracterização do grupo Edessa rufomarginata.}

O grupo se caracteriza por apresentar corpo ovalado; jugas, em vista lateral, inclinadas; distância entre os olhos maior que a metade da largura da cabeça; ângulos umerais obtusos, não-desenvolvidos; ápice do escutelo não alcança o sexto segmento do conexivo; área central na superfície ventral do abdome sem quilha; ângulos póstero-laterais do sétimo segmento abdominal curtos, menores que a metade do comprimento do laterotergito 8 nas fêmeas; comprimento dos laterotergitos 9 subiguais aos laterotergitos 8 ; coloração da face texturizada da cabeça do parâmero diferente da coloração do parâmero. O grupo E. rufomarginata possui 15 espécies de tamanho médio (11,2 - 20,7 mm) com distribuição sul-americana com exceção de E. rufomarginata, que ocorre do México ao norte da Argentina. Edessa rufomarginata, E. albomarginata e E. marginalis (Figs. 13) foram redescritas e diferenciadas em SiLVA et al. (2004).

Chave para as espécies do grupo Edessa rufomarginata.

1. Búculas sub-retilíneas; pigóforo com $1+1$ escavações laterais 10

Búculas projetadas triangularmente; pigóforo sem esta característica .................................... 2

2(1). Cabeça dos parâmeros com duas projeções (Fig. 34)

Cabeça dos parâmeros com uma projeção (Fig. 28)
3(2). Processos da taça genital reduzidos (Fig. 41) ... 4

Processos da taça genital não-reduzidos (Fig. 33)

4(3). Processos da taça genital muito reduzidos, em formato de aba; $10^{\circ}$ segmento dos machos com a face posterior declivente, com pequenos sulcos e uma carena central baixa (Figs. 41, 27) E. virididorsata $\mathrm{sp}$. nov.

Processos da taça genital reduzidos, em formato de bastão, plano na extremidade; $10^{\circ}$ segmento dos machos com a face posterior fortemente declivente e lisa (Figs. 35, 21)

E. brasiliensis sp. nov.

5(3). Décimo segmento nos machos com a face posterior emarginada (Fig. 26) .............................. 6

Décimo segmento nos machos com a face posterior não-emarginada (Fig. 16) .............. 7

6(5). Primeiro segmento do rostro mais longo que as búculas .....E. rufomarginata (De Geer, 1773)

Primeiro segmento do rostro do mesmo comprimento das búculas ............. E. rufodorsata sp. nov.

7(5). Conexivo branco-amarelado, com uma linha longitudinal formada por pontos castanhos E. castaneolineata sp. nov.

Sem esta característica .................................. 8

8(7). Pontuação negra abundante por todo o corpo; bordo dorsal do pigóforo sem abas (Fig. 20)

E. nigropunctata Berg, 1884

Pontuação negra escassa; bordo dorsal do pigóforo com duas abas

E. albomarginata (Stål, 1855)

9(2). Face externa da cabeça dos parâmeros com uma esculturação helicoidal; $10^{\circ}$ segmento nos machos com leve carena na face posterior ... E. marginalis (Dallas, 1851)

Face externa da cabeça dos parâmeros sem esculturação helicoidal; $10^{\circ}$ segmento nos machos com três carenas na face posterior (Fig. 28) ............... E. abdominalis Erichson, 1848

10(1). Bordo posterior do cório oblíquo; cabeça dos parâmeros com duas projeções

E. corallipes Erichson, 1848

Bordo posterior do cório com outro formato; cabeça dos parâmeros com uma projeção anterior

11(10). Bordo posterior do cório sinuoso; $10^{\circ}$ segmento nos machos com um par de sulcos cobertos por pêlos (Figs. 18, 25) ............................. 12

Bordo posterior do cório arredondado; $10^{\circ}$ segmento nos machos sem sulcos cobertos por pêlos (Figs. 19, 23, 24) ...................... 13

12(11). Machos com a face posterior do $10^{\circ}$ segmento com um sulco longitudinal; projeção mamiliforme na margem posterior dos gonocoxitos 8 pequena (Figs. 18, 44)

E. aulacosterna Stål, 1872

Machos com a face posterior do $10^{\circ}$ segmento sem sulco longitudinal; projeção mamiliforme na margem posterior dos gonocoxitos 8 ausente (Figs. 25, 51)

E. luteovenulata $\mathrm{sp}$. nov.

13(11). Face posterior do $10^{\circ}$ segmento nos machos com 
uma carena longitudinal; processos da taça genital pouco visíveis (Fig. 19)

E. ovalis Stål, 1872

Face posterior do $10^{\circ}$ segmento nos machos com três carenas longitudinais; processos da taça genital bem visíveis (Figs. 23, 24)

14(13). Primeiro segmento do rostro mais longo que as búculas; bordo ventral do pigóforo com recorte central em "u"E. cerradensis sp. nov.

Primeiro segmento do rostro tão longo quanto as búculas; bordo ventral do pigóforo com recorte central em " $\mathrm{v}$ "

E. chapadensis sp. nov.

\section{Edessa abdominalis Erichson, 1848}

(Figs. 4, 16, 28, 29, 42)

Edessa abdominalis ERICHSON, 1848:611; WALKER, 1867:428; STÅL, 1872:60; Distant, 1880:99; Lethierry \& SEVERin, 1893:188; KiRKALDY, 1909:154; Silva et al., 2004:267.

Aceratodes discolor Dallas, 1851:334; Walker, 1867:453; STÅL, 1872:57; SiLva et al., 2004:267.

Diagnose. Face dorsal verde; face ventral, antenas e pernas castanho-claras; bordos ântero-laterais do pronoto e terço anterior do bordo costal do cório branco-amarelados; conexivo vermelho; superfície ventral do abdome com pontuação clara, muito fina e esparsa. Cabeça dos parâmeros com projeção dirigida anteriormente, alongada, com ápice arredondado. Processos da taça genital em forma de bastão, com a face superior escavada. Décimo segmento sem sulco e com a face posterior truncada, rugosa e três leves carenas, sendo a do meio mais pronunciada. Bordo posterior dos gonocoxitos 8 formando um arco fechado e bordo sutural sem recorte.

Descrição. Comprimento 12,2-14,2; largura 7,1-8,5, corpo ovalado (Fig. 4). Face dorsal verde; face ventral, antenas e pernas castanho-claras; bordos ântero-laterais do pronoto e terço anterior do bordo costal do cório amarelados; conexivo vermelho. Jugas com pequenos sulcos transversais e sem pontuação, arredondadas e curvadas ventralmente no ápice. Tubérculos anteníferos com dente reduzido; antenômeros 1 a 4 em ordem crescente de comprimento, 4 e 5 subiguais. Rostro atingindo a primeira bifurcação do processo do metasterno, com o primeiro segmento mais longo que as búculas; segundo segmento subigual ao terceiro e quarto juntos. Búculas paralelas, inclinadas e largas. Pronoto declivente, com sulcos transversais; cicatrizes subcalosas não-pontuadas. Ângulos umerais nãodesenvolvidos. Ângulos ântero-laterais armados com um pequeno dente inconspícuo. Margem ântero-lateral reta, íntegra e levemente emarginada. Escutelo com pontuação clara mais fina que a do pronoto, com o ápice semiarredondado. Cório com veias sem diferença de coloração e com pontuação clara. Membrana do hemiélitro brilhante, variando de castanha a negra. Superfície ventral do pronoto com pontuação clara muito esparsa. Mesosterno com carena mediana mais desenvolvida na metade anterior. Processo metasternal sem pontuação, mais longo que largo, glabro, bifurcação anterior do processo metasternal divergente e com os ápices evanescentes, atingindo o terço posterior do mesosterno e acomodando o quarto e parcialmente o terceiro segmentos do rostro. Área evaporatória sem pontuação, rugosa, fosca e com a mesma cor da face ventral do corpo; peritrema ostiolar atingindo 2/3 da largura da metapleura. Abdome: conexivo com pontuação fina, ângulos póstero-laterais do conexivo e posteriores do sétimo segmento pouco desenvolvidos e agudos. Face dorsal do abdome negra; superfície ventral com pontuação clara, fina e esparsa. Tricobótrios externos à linha dos espiráculos.

Genitália do macho (Fig. 16). Pigóforo retangular em vista dorsal, com abertura dorso-posterior e ângulos póstero-laterais arredondados; superfície ventral com pontuações e sulcos no terço posterior. Cabeça dos parâmeros com uma projeção dirigida anteriormente, alongada, com ápice arredondado (Fig. 28). Face externa da cabeça do parâmero com uma área sulcada e esculturação variada; face superior sinuosa. Processos da taça genital em forma de bastão, com a face superior escavada (Fig. 29). Décimo segmento com margem posterior não-projetada, sem sulco e com pêlos; face posterior truncada, rugosa e com três leves carenas, sendo a do meio mais pronunciada.

Genitália da fêmea (Fig. 42). Gonocoxitos 8 pilosos, pontuados e no mesmo plano das demais placas genitais. Bordo posterior do gonocoxito 8 formando um arco fechado; bordo sutural sem recorte. Gonocoxitos 9 pilosos e não-pontuados, de formato trapezoidal e pouco convexo, sem carena mediana. Laterotergitos 8 nãopontuados, com as projeções de comprimento subigual aos laterotergitos 9. Laterotergitos 9 não-pontuados, ultrapassando o bordo posterior da banda que une dorsalmente os laterotergitos 8. Décimo segmento plano.

Distribuição. Venezuela (Bolivar, Guaribo), Suriname, Guiana e Brasil (Mato Grosso do Sul).

Material examinado: "BRITISH GUYANA", lectótipo aqui designado, o’, R. Schomburg col. (ZMHB); paralectótipos aqui designados, 3 ơ,, , R. Schomburg col. (ZMHB); VENEZUELA, Bolivar: San Francisco, O’, 26.X.1966, J., B. Bechyné \& E. Osuna col. (MIZA); Agua Fria, +, 28.X.1966, J., B. Bechyné \& E. Osuna col. (MIZA); Guaribo: El Sombrero, O', 11.XII.1951, H.B. \& R.B. col. (MIZA); SURINAME, 2 +, P. v. Doesburg Jr. col. (RMNH); Pbi- Brownsberg, Km 54, o', 19.VII.1975, L. Rolston col. (RMNH); BRASIL, Mato Grosso do Sul: Miranda (Pousada Caiman), O', 22.I.1992, M. de Sousa col. (UFRG).

\section{Edessa corallipes Erichson, 1848}

(Figs. 5, 17, 30, 31, 43)

Edessa corallipes ERICHSON, 1848:611; WALKER, 1867:428; STÅL, 1872:60; Lethierry \& Severin, 1893:189; KirKaldy, 1909:156.

Diagnose. Superfície dorsal e ventral castanhoescura com pontuações negras; antenas e pernas amareladas; cório com pontuação da margem costal grosseira. Face ventral do abdome com pontuação fina e esparsa. Cabeça do parâmero com duas projeções afiladas: uma dirigida internamente, mais curta e outra externa, mais longa. Processo da taça genital em forma de bastão, com a metade superior comprimida dorsoventralmente e a face superior escavada. Décimo segmento apresentando sulcos, face posterior truncada, lisa e com um sulco mediano. Bordo posterior dos gonocoxitos 8 com pequena projeção mamiliforme; bordo sutural reduzido, deixando visível as gonapófises 9; 
laterotergitos 9 estriados, ultrapassando levemente o bordo posterior da banda que une dorsalmente os laterotergitos 8 .

Descrição. Comprimento 13,7-16,4; largura 7,3-8,8, corpo ovalado (Fig. 5). Coloração dorsal e ventral castanho-escura com pontuações negras; antenas e pernas amareladas. Jugas arredondadas e curvadas ventralmente no ápice, com pequenos sulcos transversais e pontuadas. Tubérculos anteníferos com dente. Primeiro antenômero tão longo quanto o segundo, terceiro maior que o segundo, quarto maior do que o segundo e terceiro juntos e subigual ao quinto. Rostro atingindo a primeira bifurcação do processo do metasterno, com o primeiro segmento mais longo que as búculas; segundo segmento menor que o terceiro e quarto juntos. Búculas paralelas, inclinadas e largas. Pronoto declivente; cicatrizes subcalosas, não-pontuadas. Ângulos ântero-laterais armados com pequeno dente inconspícuo. Ângulos umerais não-desenvolvidos. Margem ântero-lateral reta, íntegra e levemente emarginada. Superfície ventral do pronoto pontuada. Escutelo com pontuação clara, mais fina e esparsa que a do pronoto e com o ápice afilado. Cório com veias uniformes na coloração e com pontuação da margem costal grosseira. Membrana do hemiélitro brilhante, variando de castanha à negra. Mesosterno com carena mediana mais desenvolvida na metade anterior. Processo metasternal sem pontuação, mais longo que largo e com pilosidade esparsa nos bordos; bifurcação anterior pouco divergente e com os ápices evanescentes, atingindo o terço mediano do mesosterno e acomodando o quarto e parcialmente o terceiro segmento do rostro. Área evaporatória sem pontuação, rugosa, fosca e com a mesma cor da face ventral; peritrema ostiolar atingindo 3/4 da largura da metapleura. Abdome com conexivo da mesma cor que a face dorsal do corpo e com pontuação fina. Ângulos póstero-laterais do conexivo e posteriores do sétimo segmento pouco desenvolvidos e agudos. Face dorsal do abdome negra; face ventral com pontuação fina e esparsa. Tricobótrios: um na mesma linha dos espiráculos e outro externo.

Genitália do macho (Fig. 17). Pigóforo subretangular em vista dorsal, com abertura dorso-posterior e ângulos póstero-laterais arredondados; superfície ventral com pontuações e estrias no terço posterior. Cabeça dos parâmeros com duas projeções afiladas: uma dirigida internamente, mais curta e outra externa, mais longa (Fig. 30). Face posterior da cabeça do parâmeros lisa; face anterior com rugosidade fina. Processos da taça genital em forma de bastão, com a metade superior comprimida dorso-ventralmente e com a face superior escavada (Fig. 31). Décimo segmento com margem posterior não-projetada e com sulcos cobertos por pêlos; face posterior truncada, lisa e com sulco mediano.

Genitália da fêmea (Fig. 43). Gonocoxitos 8 pilosos, em plano um pouco acima das demais placas genitais. Bordo posterior do gonocoxito 8 formando um arco fechado, com uma pequena projeção mamiliforme; bordo sutural sem recorte, reduzido, deixando visíveis as gonapófises 9. Gonocoxitos 9 pilosos e não-pontuados, trapezoidais e convexos, com leve carena mediana. Laterotergitos 8 pontuados e de comprimento subigual aos laterotergitos 9. Laterotergitos 9 pontuados e estriados, ultrapassando levemente o bordo posterior da banda que une dorsalmente os laterotergitos 8 . Décimo segmento levemente convexo e estriado.

Distribuição. Colômbia (Antioquia, Bogotá, Meta), Venezuela (Bolívar, Monagas), Suriname (Paramaribo, Para), Guiana, Guiana Francesa (Caiena), Brasil (Amapá, Pará, Mato Grosso, Minas Gerais, São Paulo), Bolívia (Santa Cruz), Paraguai (Concepción, Cordillera) e Argentina (Misiones).

Material examinado. Holótipo o", "British Guyana, R. Schomburg col." (ZMHB); COLÔMBIA, Antioquia: Medellin, †, 1071-74 (MNHN); Bogotá: Bogotá, ㅇ (MNHN); Meta Villavicencio, O, 2 \& (CAS). VENEZUELA, Distrito Federal: Caracas, $q$, 6.X.1991, Meinartl. (ZMUC); Monagas: Jusepin, $q$, o', 15-IX-1965, F. Fernandes e C. J. Rosales col. (en Guayaba de sabana) (MIZA); Caripe, + , 19.X.1965, F. Fernandes \& C. Rosales col. (MIZA); Bolívar: Guayaraca (Auyantepui), ㅇ, 14.IV.1956, F. Fernandes \& C. Rosales col. (MIZA). SURINAME, Paramaribo: Paramaribo,, , 25-II-1962, P. H. van Doesburg (RMNH); Lÿn, 2 ơ, 13.X.1948 (RMNH); ᄋ, 8.XII.1963, D. Geijskes col. (RMNH); Para: Zanderij, $\odot, 20$-VIII-1958, Geijskes col. (RMNH). GUIANA FRANCESA, Caiena: Les Roches de Kourou, ơ, + , Le Moult (MNHN). BRASIL, Amapá: Porto Platon, o', 18.V.1983, J. Lacerda col. (UFRG); Pará: Tumucumaque, ơ, + , 28.I.1981, E. Oliveira col. (UFRG); Mato Grosso: Cuiabá, + , 30.I.1980, D. Thomas col. (UFRG); Minas Gerais: Poços de Caldas (Morro do Ferro), 2 \&, o', 2-VII-1967, J. Becker col. (RMNH); São Paulo: Barueri, O', III-1955, K. Lenko col (RMNH). BOLÍVIA, Santa Cruz: Santa Cruz de la Sierra, + , $450 \mathrm{~m}$, J. Steinbach col., 5569 (CMNH). PARAGUAI, Concepción: Horqueta,, , 15-II-1934 (CAS); Cordillera: San Bernardino, ơ,, , Fiebrig S. V. col. (ZMHB). ARGENTINA, Misiones: Loreto, 2 , , on, IX-1955, F. H. Walz col. (RMNH).

\section{Edessa aulacosterna Stål, 1872}

(Figs. 6, 18, 44, 54)

Edessa aulacosterna STÅL, 1872:56; LethiERRY \& SEVERIN, 1893:188; KIRKALDY, 1909:154

Diagnose. Rostro ultrapassando a bifurcação anterior do processo do metasterno, atingindo as coxas posteriores; margem costal do cório com pontuação grosseira e clara. Tricobótrios externos à linha dos espiráculos. Pigóforo com 1+1 escavações pouco profundas na parede ventral da taça genital, apresentando $1+1$ elevações perpendiculares ao bordo dorsal no interior das escavações; processos da taça genital quadrangulares, castanho-escuros e escavados. Décimo segmento com um par de sulcos recobertos por pêlos e a face posterior com sulco longitudinal. Gonocoxitos 8 com a margem posterior irregular e pequena projeção mamiliforme; gonapófises 9 visíveis; gonocoxitos 9 com carena.

Descrição. Comprimento 17,8-20,2; largura 9,5-11,2, corpo levemente ovalado (Fig. 6). Coloração geral verdeclara. Jugas mais longas que o clípeo, arredondadas e planas no ápice, com pequenos sulcos transversais, sem pontuação. Búculas paralelas. Primeiro antenômero menor que o segundo, segundo e terceiro subiguais, quarto maior que o terceiro e subigual ao quinto. Rostro ultrapassando a bifurcação anterior do processo do metasterno, atingindo as coxas posteriores. Primeiro segmento do rostro mais longo que as búculas. Segundo segmento mais longo que o terceiro e quarto reunidos. Pronoto declivente, com os ângulos ântero-laterais armados com pequeno dente. Margens ântero-laterais 
retas, íntegras e levemente emarginadas. Cicatrizes do pronoto subcalosas e não-pontuadas. Escutelo brilhante, com ápice levemente acuminado e pontuação mais fina que o pronoto. Cório fosco, com pontuação mais fina e densa que o resto do corpo e veias sem diferença de coloração; margem costal do cório com pontuação grosseira e clara. Membrana do hemiélitro castanha, brilhante. Mesosterno pontuado, com carena mediana baixa que avança até as coxas anteriores. Processo metasternal mais longo que largo, achatado, sulcado longitudinalmente e glabro; bifurcação anterior do processo metasternal divergente, com os ápices evanescentes, atingindo o terço mediano do mesosterno, acomodando parcialmente o segundo segmento do rostro e sendo ultrapassada pelo terceiro e quarto segmentos. Área evaporatória rugosa, fosca e com a mesma cor da face ventral; peritrema ostiolar atingindo $4 / 5$ da largura da metapleura. Abdome com conexivo da mesma cor da face dorsal e pontuação fina, densa. Ângulos pósterolaterais do conexivo e posteriores do sétimo segmento pouco desenvolvidos e agudos. Face dorsal do abdome castanho-clara; superfície ventral com pontuação fina. Tricobótrios externos à linha dos espiráculos.

Genitália do macho (Fig. 18). Pigóforo retangular em vista dorsal; abertura dorso-posterior e ângulos póstero-laterais arredondados; superfície ventral com pontuações e sulcos variáveis (Fig. 54); bordo ventral com recorte mediano em " $u$ " aberto. Pigóforo com 1+1 escavações pouco profundas na parede ventral da taça genital. Interior das escavações com $1+1$ elevações perpendiculares ao bordo dorsal. Parâmeros com cabeça e pé geniculados, sendo a primeira voltada para a região anterior, face ântero-lateral escura, com textura diferenciada e direcionada para o processo da taça genital. Processos da taça genital quadrangulares, castanhoescuros, escavados e situados junto ao bordo dorsal do pigóforo. Décimo segmento cilíndrico, com um par de sulcos recobertos por pêlos; face posterior declivente, com um sulco longitudinal.

Genitália da fêmea (Fig. 44). Gonocoxitos 8 pontuados, situados no mesmo plano que as demais placas genitais, com o bordo posterior irregular, dotados de uma pequena projeção mamiliforme; bordos suturais curtos, deixando visíveis as gonapófises 9. Gonocoxitos 9 planos, carenados. Laterotergitos 8 com a extremidade pouco afilada, com as projeções mais longas do que os laterotergitos 9. Laterotergitos 9 com projeção afilada, pouco pronunciada, ultrapassando levemente o bordo posterior da banda que une dorsalmente os laterotergitos 8 . Gerais).

Distribuição. Brasil (Goiás, Mato Grosso e Minas

Material examinado. BRASIL ("Brasília"), holótipo o (NHRM); O (ZMHB); Goiás: Curumbá de Goiás, ơ, 04.II.1962, J. \& B. Bechyné col. (MPEG); Mato Grosso: Chapada [dos Guimarães], $15^{\circ} 26^{\prime} \mathrm{S}, 55^{\circ} 45^{\prime} \mathrm{W}$, ㅇ, 1882-1884, H. Smith col. $(\mathrm{CMNH})$; Minas Gerais: Tiradentes (Serra de São José), O’, 25.X.1989, J. Becker col. (RMNH)

\section{Edessa ovalis Stål, 1872}

(Figs. 7, 19, 45, 55)

Edessa ovalis StÅl, 1872:57; Lethierry \& Severin, 1893:192; KIRKALDY, 1909:161.
Diagnose. Rostro com o primeiro segmento tão longo quanto as búculas; margem costal do cório com pontuação grosseira e escura. Um tricobótrio na mesma linha dos espiráculos e outro externo. Pigóforo com 1+1 escavações arredondadas e profundas na parede ventral da taça genital; processos da taça genital quadrangulares, pouco visíveis e castanhos. Décimo segmento nãosulcado e com a face posterior declivente, com uma carena longitudinal. Gonocoxitos 8 apresentando a margem posterior com projeção afilada, não cobrindo as gonapófises 9; gonocoxitos 9 sem carena.

Descrição. Comprimento 16,5-18,0; largura 9,4-10,1, corpo ovalado (Fig. 7). Coloração geral verde-clara; ângulos umerais não-desenvolvidos; face ventral verdeclara com estrias descoloridas. Cabeça com a superfície dorsal esparsamente pontuada. Jugas arredondadas e curvadas ventralmente no ápice, com pequenos sulcos transversais e sem pontuação. Tubérculos anteníferos com dente vestigial; primeiro antenômero menor que o segundo, segundo e terceiro subiguais, quarto maior que o terceiro e subigual ao quinto. Rostro atingindo a primeira bifurcação do processo do metasterno, com o primeiro segmento tão longo quanto as búculas; segundo segmento tão longo quanto o terceiro e quarto reunidos; búculas paralelas. Pronoto declivente, rugoso, pontuado, brilhante, com os ângulos ântero-laterais armados com um pequeno dente. Margens ântero-laterais retas, íntegras e levemente emarginadas. Cicatrizes do pronoto subcalosas e não-pontuadas. Escutelo brilhante, com ápice levemente acuminado e pontuação mais fina que o pronoto. Cório fosco, com pontuação mais fina e densa do que o resto do corpo e veias sem diferença de coloração; margem costal do cório com pontuação grosseira e escura. Membrana do hemiélitro castanhoclara, brilhante. Superfície ventral do pronoto com pontuação. Mesosterno pontuado, com uma carena mediana baixa que avança até as coxas anteriores. Processo metasternal mais longo que largo, achatado, liso e glabro. Bifurcação anterior do processo metasternal curta, divergente, com os ápices evanescentes, atingindo o limite do terço posterior do mesosterno e acomodando parcialmente o quarto segmento do rostro. Área evaporatória rugosa, fosca e com a mesma cor da face ventral; peritrema ostiolar atingindo a metade da largura da metapleura. Conexivo com pontuação muito fina e densa. Ângulos póstero-laterais do conexivo pouco desenvolvidos e levemente agudos. Ângulos posteriores do sétimo segmento não-desenvolvidos. Face dorsal do abdome castanho-escura; superfície ventral com pontuação grosseira e esparsa. Tricobótrios: um na mesma linha dos espiráculos e outro externo.

Genitália do macho (Fig. 19). Pigóforo levemente triangular em vista dorsal; abertura dorso-posterior e ângulos póstero-laterais arredondados; superfície ventral com pontuações e sulcos variáveis (Fig. 55); bordo ventral com recorte mediano em "u" aberto. Pigóforo com $1+1$ escavações arredondadas e profundas na parede ventral da taça genital. Parâmeros com cabeça e pé geniculados, sendo a cabeça voltada para a região anterior; face ântero-lateral escura, com textura diferenciada e direcionada para o processo da taça genital. Processos da taça genital quadrangulares, pouco visíveis, 
castanhos, situados junto ao bordo dorsal do pigóforo. Décimo segmento cilíndrico, com pilosidade esparsa, nãosulcado; face posterior declivente, com uma carena longitudinal.

Genitália da fêmea (Fig. 45). Gonocoxitos 8 pontuados, situados no mesmo plano que as demais placas genitais, com o bordo posterior dotado de uma projeção afilada. Gonocoxitos 9 planos, destituídos de carena. Laterotergitos 8 com as projeções curtas, subiguais aos laterotergitos 9 . Laterotergitos $9 \mathrm{com}$ as extremidades arredondadas, ultrapassando conspicuamente o bordo posterior da banda que une dorsalmente os laterotergitos 8 .

Distribuição. Brasil (Pará, Mato Grosso e Rio de Janeiro), Paraguai (Cordillera) e Argentina (Misiones).

Material examinado. BRASIL ("Brasilien"), holótipo 오, Signoret col. (NHMW); O' (ZMHB); Pará: Vigia, +, 27.V.1978, P. Tadeu col. (MPEG); Benevides, + , V.1964, W. França col. (UFRG); Bragança, O’, + , 26.V.1978, R. Neto col. (UFRG); Mato Grosso: Chapada dos Guimarães, +, 01.II.1961, J. \& B. Bechyné col. (MPEG); Rio de Janeiro: Porto das Caixas (Fazenda Maracú), 2 †, I-III.1921, Coleção Jensen-Haarup (ZMUC). PARAGUAI,, , Fiebrig S. V. col., 5517 (ZMHB); Cordillera: San Bernardino, ơ, ㅇ, Fiebrig S. V. col. (em Anona sp.) (ZMHB). ARGENTINA, Misiones: + (MLPA).

\section{Edessa nigropunctata Berg, 1884}

(Figs. 8, 20, 32, 33, 46)

Edessa nigropunctata Berg, 1884:32; Lethierry \& Severin, 1893:192; KiRKALDY, 1909:161.

Diagnose. Face dorsal, face ventral e pernas castanho-claras; antenas alaranjadas; pontuação negra em todo o corpo. Tubérculos anteníferos sem dente. Pronoto com cicatrizes subcalosas alaranjadas e pontuadas; processo metasternal com pontuação negra. Conexivo da mesma cor que a face dorsal, apresentando duas listras escuras por segmento, formadas pela justaposição da pontuação negra. Espiráculos elípticos, com uma área alaranjada ao seu redor que atinge a margem anterior do respectivo segmento. Cabeça do parâmero com duas projeções, uma retangular na lateral externa e outra estreita e alongada na lateral interna. Processos da taça genital retangulares, achatados, fendidos medianamente e encobertos parcialmente pelos parâmeros, sendo o braço inferior mais longo, afilado e encurvado para baixo. Décimo segmento sem sulcos e pêlos; face posterior truncada, com uma depressão mediana em "v", rugosa e sem carenas. Bordo posterior do gonocoxito 8 formando um arco; bordo sutural com recorte no terço posterior.

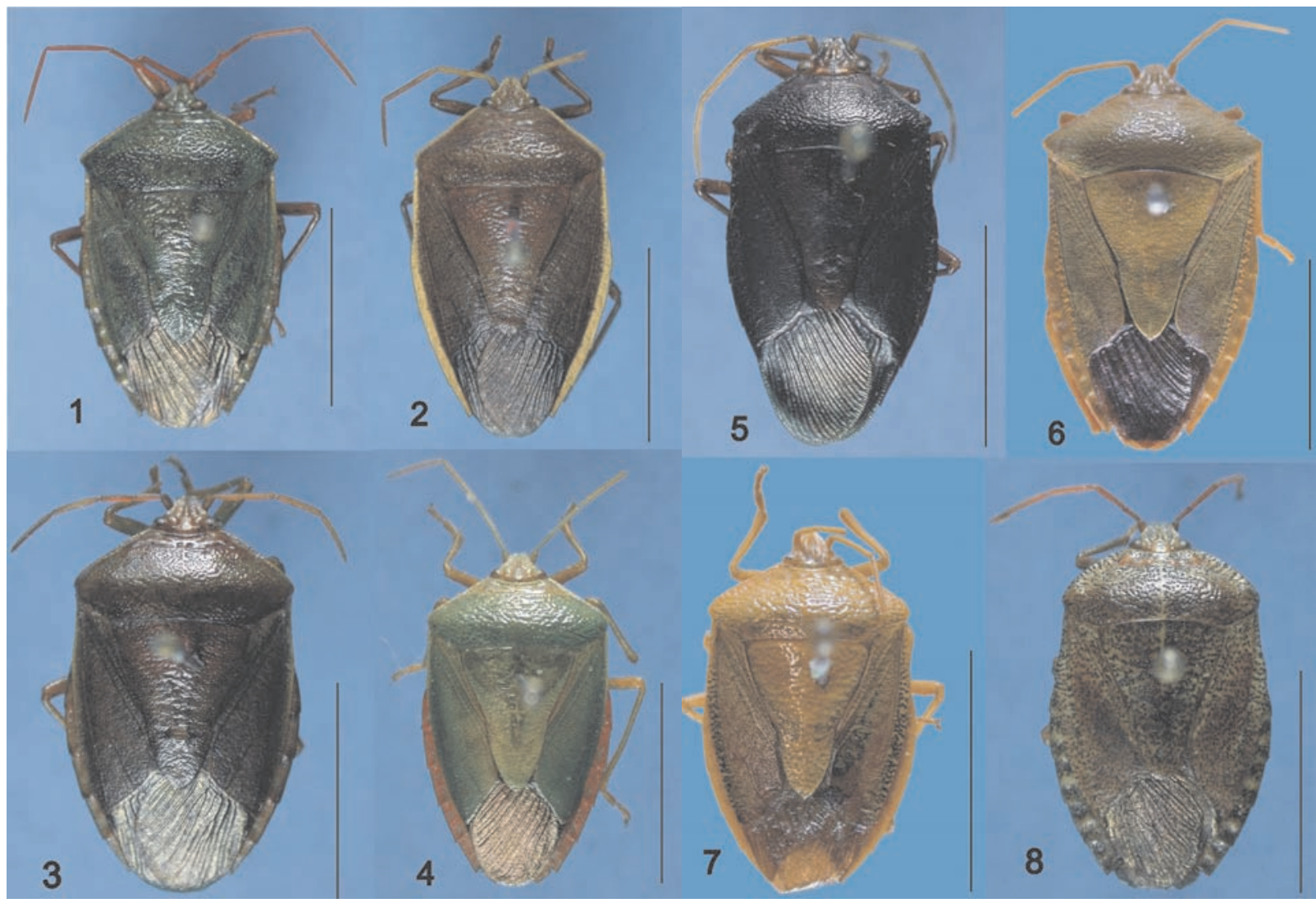

Figs. 1-8. 1, Edessa rufomarginata (De Geer, 1773); 2, Edessa marginalis (Dallas, 1951); 3, Edessa albomarginata (Stål, 1855); 4, Edessa abdominalis Erichson, 1848; 5, Edessa corallipes Erichson, 1848; 6, Edessa aulacosterna Stål, 1872; 7, Edessa ovalis Stål, 1872; 8, Edessa nigropunctata Berg, 1884. Escalas $=10 \mathrm{~mm}$. 
Descrição. Comprimento 12,5-14,9 mm; largura 8,4$9,8 \mathrm{~mm}$, corpo ovalado (Fig. 8). Face dorsal, face ventral e pernas castanho-claras; antenas alaranjadas; pontuação negra em todo o corpo. Jugas arredondadas e curvadas ventralmente no ápice, com pequenos sulcos transversais pontuados. Tubérculos anteníferos sem dente; antenômeros em ordem crescente de comprimento. Rostro atingindo a primeira bifurcação do processo do metasterno, com o primeiro segmento mais longo que as búculas; segundo segmento subigual ao terceiro e quarto juntos. Búculas paralelas, inclinadas e largas. Pronoto declivente, com sulcos transversais; cicatrizes subcalosas alaranjadas e pontuadas. Ângulos umerais não-desenvolvidos. Ângulos ântero-laterais com um pequeno dente inconspícuo. Margem ântero-lateral levemente sinuosa, íntegra e não-emarginada. Superfície ventral com pontuação negra. Escutelo com ápice arredondado. Cório com veias sem diferença de coloração. Membrana do hemiélitro brilhante, variando de castanhoescura a negra. Mesosterno com carena mediana no final do terço anterior. Processo metasternal com pontuação negra, mais longo que largo e glabro; bifurcação anterior do processo metasternal divergente, com os ápices evanescentes, atingindo o terço posterior do mesosterno e acomodando parcialmente o quarto segmento do rostro. Área evaporatória com pontuação negra, rugosa, fosca e com a mesma cor da face ventral; peritrema ostiolar atingindo $2 / 3$ da largura da metapleura. Abdome da mesma cor que o restante da superfície dorsal, apresentando duas listras escuras por segmento, formadas pela justaposição da pontuação negra, sendo o restante da superfície não-pontuada. Ângulos pósterolaterais do conexivo e posteriores do sétimo segmento pouco desenvolvidos. Face dorsal do abdome negra; superfície ventral com pontuação negra. Espiráculos com uma área alaranjada ao seu redor, que atinge a margem anterior do segmento; tricobótrios na mesma linha dos espiráculos.

Genitália do macho (Fig. 20). Pigóforo retangular em vista dorsal, com abertura dorso-posterior e ângulos póstero-laterais arredondados; superfície ventral com pontuações na metade posterior. Cabeça do parâmero com duas projeções: uma retangular na lateral externa e outra estreita e alongada na lateral interna; face anterior escura, com textura diferenciada, face posterior sulcada junto às projeções (Fig. 32). Processo da taça genital retangular, achatado, fendido medianamente e encoberto parcialmente pelo parâmero, sendo o braço inferior mais longo, afilado e encurvado para baixo (Fig. 33). Décimo segmento com margem posterior não-projetada, nãosulcada e sem pêlos; face posterior truncada, com uma depressão mediana em "v", rugosa e sem carenas.

Genitália da fêmea (Fig. 46). Gonocoxitos 8 pilosos, pontuados e no mesmo plano das demais placas genitais. Bordo posterior do gonocoxito 8 formando um arco; bordo sutural com um recorte no terço posterior. Gonocoxitos 9 pilosos e pontuados, trapezoidais e convexos, freqüentemente com carena mediana. Laterotergitos 8 pontuados, com as projeções subiguais ao comprimento dos laterotergitos 9. Laterotergitos 9 pontuados, mal ultrapassando a banda que une dorsalmente os laterotergitos 8. Décimo segmento convexo.

Distribuição. Brasil (Minas Gerais, Rio de Janeiro, São Paulo e Rio Grande do Sul), Uruguai (Montevideo) e Argentina (Córdoba, Entre Ríos e Corrientes).

Material examinado. URUGUAI, Montevideo, holótipo ㅇ, J. Arechavaleta col. (ZMHB). BRASIL, ơ , $q$ (MLPA); Minas Gerais: Uberlândia (Parque Estadual Intervales), 3 ơ, 2 , XII.2005, G. Requena col. (UFRG); Rio de Janeiro: Nova Friburgo (Mury), O', , X, XII.1980, Gred \& Guimarães col. (MZSP); São Paulo: Itu (Fazenda Pau d'Alho),, , 27.XII.1959, U. Martins (MZSP); Rio Grande do Sul: Cambará do Sul (cânion do Faxinal), O', 29.XII.1983, S. Bonatto col. (UFRG); Pinhal, , 20.X.1939 (UFRG); ARGENTINA, Córdoba: Calamuchita (E1 Sauce), , XII.1938, M. Viana col. (MACN); Punilla (Los Cocos), 2 ơ, 2 +, XII.1946, M. Viana col. (MACN); Entre Ríos: Pronunciamento,, , XII.1964, F. Walz col. (RMNH); Concordia, ơ, ㅇ, 1965, A. Pirán col. (MACN); Corrientes: San Tomé, ㅇ, X.1924 (MACN); O', III.1925, (MACN); 2 O', I.1928 (MACN).

\section{Edessa brasiliensis sp. nov.} (Figs. 9, 21, 34, 35, 47)

Etimologia. Epíteto alusivo a Brasília, município de procedência de parte do material-tipo.

Descrição. Comprimento 11,2-13,4; largura 5,9-7,7, corpo ovalado (Fig. 9). Face dorsal verde no pronoto, escutelo e conexivo, cório castanho; face ventral verde; pernas e antenas alaranjadas. Jugas com pequenos sulcos transversais e pontuadas, arredondadas e curvadas ventralmente no ápice. Tubérculos anteníferos com dente reduzido; primeiro e segundo antenômeros subiguais, terceiro o dobro do segundo, quarto maior que o terceiro e menor que o quinto. Rostro atingindo a primeira bifurcação do processo do metasterno; primeiro segmento do mesmo comprimento do que as búculas; segundo segmento maior que o terceiro e este maior que o quarto. Búculas paralelas, não-inclinadas e estreitas. Pronoto declivente, levemente rugoso, com pontuação clara e cicatrizes subcalosas não-pontuadas. Ângulos umerais não-desenvolvidos. Ângulos ântero-laterais com um pequeno dente inconspícuo. Margem ântero-lateral reta, íntegra, pouco sulcada e emarginada. Superfície ventral com pontuação castanho-clara. Escutelo com ápice afilado e pontuação clara, fina. Cório castanho, veias sem diferença de coloração e margem costal castanhoclara, apresentando pontuação escura grosseira. Membrana do hemiélitro brilhante, castanho-escura. Mesosterno com carena mediana reduzida, elevada apenas na metade anterior. Processo metasternal mais longo que largo e piloso nas margens; bifurcação anterior divergente e com os ápices evanescentes, atingindo o terço posterior do mesosterno, acomodando o quarto segmento do rostro. Área evaporatória rugosa, fosca e com a mesma cor da face ventral; peritrema ostiolar atingindo $3 / 5$ da largura da metapleura. Abdome apresentando conexivo com pontuação fina. Ângulos póstero-laterais do conexivo e ângulos posteriores do sétimo segmento agudos e não-desenvolvidos. Face dorsal do abdome castanho-escura; superfície ventral ligeiramente rugosa. Tricobótrios externos à linha dos espiráculos do terceiro ao sexto segmentos, no sétimo um tricobótrio na linha e o outro externo ao espiráculo. 

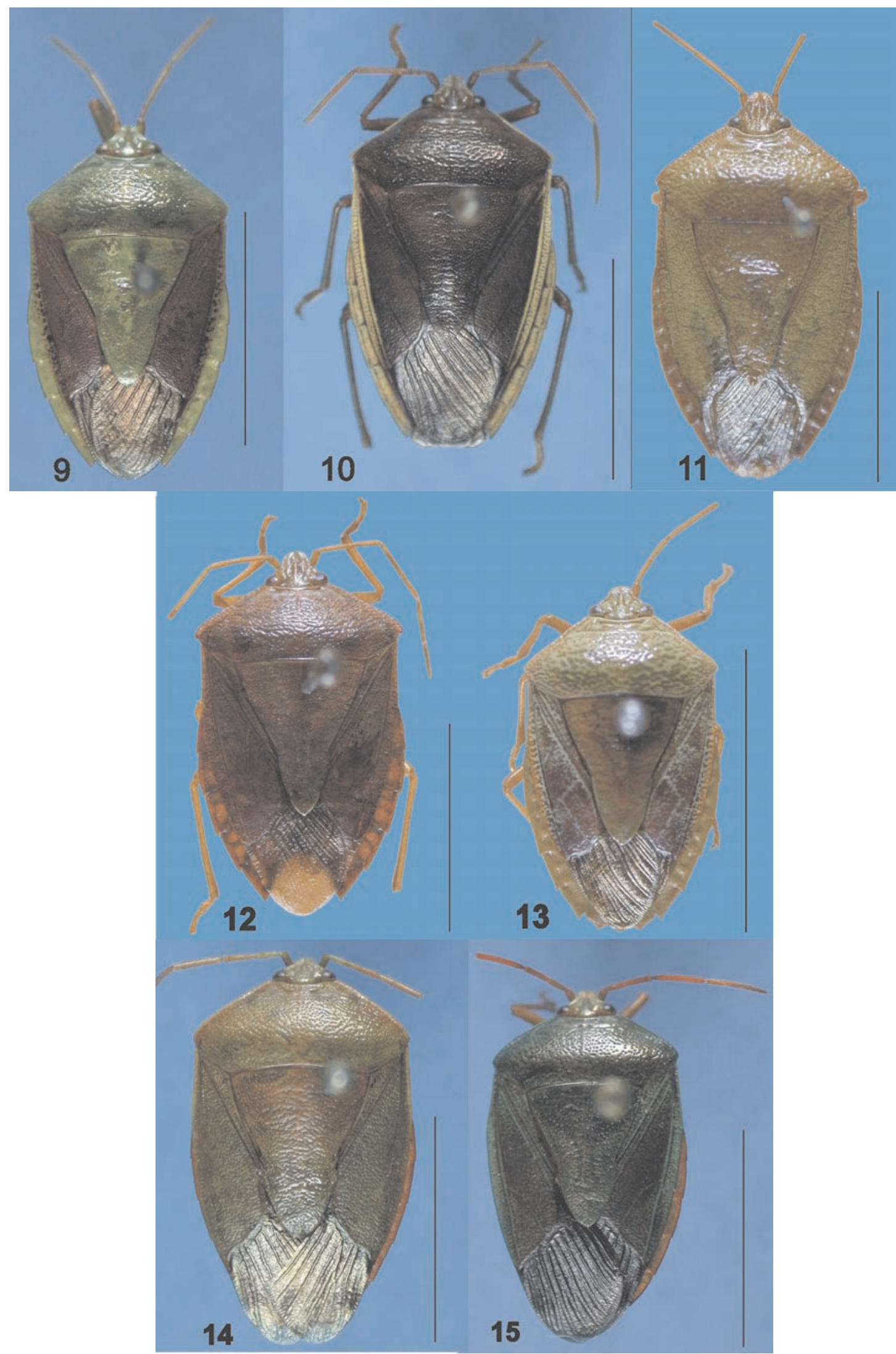

Figs. 9-15. 9, Edessa brasiliensis sp. nov., parátipo o'; 10, Edessa castaneolineata sp. nov., parátipo O; 11, Edessa cerradensis sp. nov., parátipo क; 12, Edessa chapadensis sp. nov., holótipo o'; 13, Edessa luteovenulata sp. nov., parátipo o; 14, Edessa rufodorsata sp. nov., parátipo ; 15, Edessa virididorsata sp. nov., holótipo $\sigma^{\top}$. Escalas $=10 \mathrm{~mm}$. 
Genitália do macho (Fig. 21). Pigóforo retangular em vista dorsal, com abertura dorso-posterior; sem pilosidade na taça genital; ângulos póstero-laterais arredondados; bordo ventral recurvado em direção à abertura do pigóforo; superfície ventral com pontuação esparsa e sulcos na metade posterior. Cabeça do parâmero com duas projeções: uma externa afilada, alongada e recurvada e outra interna, reduzida e retangular (Fig. 34); face anterior escura e de textura diferenciada, face posterior lisa. Processo da taça genital reduzido, de formato irregular, com uma depressão na face superior (Fig. 35). Décimo segmento cilíndrico, com margem posterior não-projetada e sem sulcos; face posterior fortemente declivente e lisa.

Genitália da fềmea (Fig. 47). Gonocoxitos 8 pilosos, pontuados e no mesmo plano que as demais placas genitais; bordo posterior em arco levemente sinuoso; bordo sutural com recorte no terço posterior. Gonocoxitos 9 pilosos, não-pontuados, trapezoidais, convexos, sem carena mediana e bordo posterior em " $\mathrm{v}$ ". Laterotergitos 8 não-pontuados, com projeções curtas subiguais aos laterotergitos 9. Laterotergitos 9 afilados, não-pontuados e mal ultrapassando a banda que une dorsalmente os laterotergitos 8. Décimo segmento convexo e levemente estriado.

Distribuição. Brasil (Pará, Goiás, Distrito Federal e Mato Grosso).

Material-tipo. Holótipo $O^{7}$, BRASIL, Distrito Federal: Brasília, XII.1961, H. S. Lopes col. (MCNZ). Parátipos: BRASIL, Pará: Benevides (estrada PA 408 Km 6), + , 10-XI-1980, R. Neto col. (MPEG); Mato Grosso: Chapada [dos Guimarães], ơ ,, , $15^{\circ} 26^{\prime} \mathrm{S}, 55^{\circ} 45^{\prime} \mathrm{W}, 1882-1884$, H. Smith col. (CMNH); estrada Cuiabá-Poconé Km 81, 15-II-1985, M. Zanuto col., 오 (MPEG); Goiás: Fazenda Paraíso, 8-II-1962, J. \& B. Bechyné col., † (MPEG); 9-II-1962, ㅇ (MPEG); Distrito Federal: Brasília, ơ, VII.1960, H. S. Lopes col. (UFRG); 2 9, IX.1960, A. Guimarães col. (UFRG); , I.1961, H. S. Lopes col. (RMNH); ㅇ, XII.1961, H. S. Lopes col. (UFRG).

Discussão. Edessa brasiliensis sp. nov. se diferencia das demais espécies do grupo Edessa rufomarginata por apresentar cabeça do parâmero com duas projeções, uma externa afilada, alongada e recurvada e outra interna, reduzida e retangular; processo da taça genital reduzido, em formato de bastão, plano na extremidade; décimo segmento com a face posterior fortemente declivente e lisa; bordo posterior dos gonocoxitos $8 \mathrm{em}$ arco levemente sinuoso e bordo sutural com recorte no terço posterior; gonocoxitos 9 com o bordo posterior em " $\mathrm{v}$ ".

\section{Edessa castaneolineata sp. nov (Figs. 10, 22, 36, 37, 48)}

Etimologia. Epíteto alusivo à coloração do conexivo.

Descrição. Comprimento 13,4-15,0; largura 7,7-8,8, corpo ovalado (Fig. 10). Coloração castanha, com os bordos ântero-laterais do pronoto branco-amarelados, margem costal do cório branco-amarelada com pontuações castanhas e conexivo branco-amarelado, com uma linha longitudinal formada por pontos de coloração castanha e com pontuação fina e clara no resto do conexivo. Jugas pontuadas com pequenos sulcos transversais, arredondadas e curvadas ventralmente no ápice. Tubérculos anteníferos com dente vestigial. Antenômeros em ordem crescente de comprimento. Rostro atingindo a primeira bifurcação do processo do metasterno, com o primeiro segmento de mesmo comprimento que as búculas, o segundo maior do que o terceiro e este maior que o quarto. Búculas paralelas, inclinadas e largas. Pronoto com pontuação castanha e densa; cicatrizes subcalosas não-pontuadas. Ângulos umerais não-desenvolvidos. Ângulos ântero-laterais com um pequeno dente. Margem ântero-lateral reta, íntegra, levemente emarginada e não-estriada. Superfície ventral do pronoto com pontuação castanho-escura. Escutelo com pontuação castanho-escura densa. Cório com veias de coloração uniforme e com pontuação fina e densa. Membrana do hemiélitro brilhante, castanho-escura a negra. Mesosterno com pontuação castanha e carena mediana. Processo metasternal sem pontuação, mais longo que largo e com pilosidade nos bordos. Bifurcação anterior do processo metasternal pouco divergente, com os ápices evanescentes atingindo o terço posterior do mesosterno e acomodando o quarto segmento do rostro. Área evaporatória sem pontuação, rugosa, fosca e com a mesma cor da face ventral; peritrema ostiolar atingindo $2 / 3$ da largura da metapleura. Abdome com os ângulos póstero-laterais do conexivo e posteriores do sétimo segmento não-desenvolvidos e agudos. Face dorsal do abdome castanho-escura; face ventral com pontuação castanho-escura. Tricobótrios: um externo e outro na linha dos espiráculos.

Genitália do macho (Fig. 22). Pigóforo retangular em vista dorsal, com abertura dorso-posterior e ângulos póstero-laterais arredondados; superfície ventral com pontuações castanho-escuras e estrias no terço posterior. Cabeça do parâmero com duas projeções em "v": uma dirigida anteriormente, mais larga na base e levemente afilada na extremidade, e outra posterior, não-alargada na base e arredondada no ápice (Fig. 36). Face interna da cabeça do parâmero lisa; face externa com textura diferenciada e escura. Processo da taça genital retangular, comprimido lateralmente e fendido; porção externa maior, alargada e recurvada no ápice; porção interna menor e afilada (Fig. 37). Décimo segmento com margem posterior não-projetada e sem sulcos cobertos por pêlos; face posterior pilosa, declivente, rugosa e com a área mediana elevada.

Genitália da fêmea (Fig. 48). Gonocoxitos 8 pilosos, pontuados, em um plano pouco acima das demais placas genitais e com o terço posterior deprimido. Bordo posterior do gonocoxito $8 \mathrm{em}$ arco; bordo sutural com recorte pequeno junto ao ápice. Gonocoxitos 9 pilosos e pontuados, trapezoidais, convexos e com carena mediana. Laterotergitos 8 pontuados, com a projeção curta, subigual a dos laterotergitos 9. Laterotergitos 9 pontuados, levemente estriados, subiguais ao bordo posterior da banda que une dorsalmente os laterotergitos 8. Décimo segmento plano e levemente estriado.

Distribuição: Brasil (Pará, Mato Grosso, Goiás e Distrito Federal). 
Material-tipo. Holótipo ơ, BRASIL, Mato Grosso: Chapada dos Guimarães, III.1978, O. Roppa \& A. Domingos col. (MCNZ). Parátipos. O’, Pará: Óbidos, IV.1978, A. Domingos col. (MNRJ); ㅇ (MNRJ); o', 2 \%, 05-09.IX.1978, J. Becker col. (UFRG); o', Buriti, 08.II.1961, J. \& B. Bechyné col. (MPEG); O’, ㅇ, Goiás: Corumbá de Goiás, 01-04.II.1962, J. \& B. Bechyné col. (MPEG); 3 ㅇ, Distrito Federal: Brasília, 27.III.1964, C. E. \& E. S. Ross (CAS).

Discussão. Edessa castaneolineata sp. nov. pode ser diferenciada das demais espécies do grupo Edessa rufomarginata, tanto pela coloração do conexivo, que se apresenta branco-amarelado, com uma linha longitudinal formada por pontos castanhos, como pela genitália do macho, que apresenta cabeça do parâmero com duas projeções em "v", uma dirigida anteriormente, mais larga na base e afilada levemente na extremidade, outra posterior, não-alargada na base e mais arredondada no ápice; processo da taça genital retangular, comprimido lateralmente e fendido; porção externa maior, larga e recurvada no ápice; porção interna menor e afilada; décimo segmento sem sulcos cobertos por pêlos, face posterior pilosa, declivente, rugosa e com a área mediana elevada.

\section{Edessa cerradensis sp. nov.}

(Figs. 11, 23, 49, 56)

Etimologia. Epíteto alusivo ao Cerrado, uma das regiões de procedência dos exemplares.

Descrição. Comprimento 21,4-22,4; largura 12,0-13,2, corpo levemente ovalado (Fig. 11). Coloração geral verdeclara. Cabeça pontuada; jugas com pequenos sulcos transversais, arredondadas e curvadas ventralmente no ápice. Tubérculos anteníferos com dente vestigial; antenômeros 1 a 5 em ordem crescente de comprimento. Rostro atingindo a primeira bifurcação do processo do metasterno; primeiro segmento do rostro tão longo quanto as búculas; segundo segmento menor que o terceiro e quarto reunidos; búculas paralelas. Pronoto rugoso, pontuado, brilhante, ângulos ântero-laterais com um pequeno dente. Margens ântero-laterais retas, íntegras e levemente emarginadas. Ângulos umerais nãodesenvolvidos. Cicatrizes do pronoto subcalosas e nãopontuadas. Escutelo brilhante, com ápice levemente acuminado, pontuação mais fina que o pronoto. Cório fosco, com pontuação mais fina e densa que o resto do corpo e veias sem diferença de coloração; margem costal do cório com pontuação clara igual à do pronoto. Membrana do hemiélitro descolorida, brilhante e transparente. Superfície ventral do pronoto pontuada. Mesosterno pontuado, com uma carena mediana baixa que avança até as coxas anteriores. Processo metasternal mais longo que largo, achatado, liso e glabro; bifurcação anterior do processo metasternal divergente, com os ápices evanescentes, atingindo o terço posterior do mesosterno e acomodando o quarto segmento do rostro. Área evaporatória rugosa, fosca e com a mesma cor da face ventral; peritrema ostiolar atingindo metade da largura da metapleura. Conexivo com a pontuação fina e escura. Ângulos póstero-laterais do conexivo e posteriores do sétimo segmento pouco desenvolvidos e agudos. Face dorsal do abdome castanho-clara; superfície ventral rugosa e com pontuação grosseira. Tricobótrios: um na mesma linha dos espiráculos e outro externo.

Genitália do macho (Fig. 23). Pigóforo retangular em vista dorsal; abertura dorso-posterior, ângulos póstero-laterais arredondados; superfície ventral (Fig. 56) não-sulcada, com pontuações esparsas e um par de elevações próximas ao bordo ventral; bordo ventral com recorte central em "u" fechado. Interior do pigóforo com 1+1 escavações profundas na parede ventral da taça genital. Parâmeros com cabeça mais pé geniculados, direcionados para a região anterior; cabeça com a extremidade anterior arredondada; face ântero-lateral dos parâmeros escura, com textura diferenciada e voltada para o processo da taça genital. Processos da taça genital sinuosos, castanho-escuros, brilhantes e lisos, situados junto ao bordo dorsal do pigóforo. Décimo segmento cilíndrico, com pilosidade esparsa e sem sulcos; face posterior declivente, com três carenas longitudinais, a do meio mais pronunciada e as laterais pouco distintas.

Genitália da fêmea (Fig. 49). Gonocoxitos 8 pontuados, no mesmo plano que as demais placas genitais; margem posterior recortada próximo ao bordo sutural e com projeção afilada pronunciada. Gonocoxitos 9 planos e destituídos de carena. Laterotergitos 8 com projeções afiladas pronunciadas, ultrapassando os laterotergitos 9. Laterotergitos 9 afilados, ultrapassando conspicuamente a banda que une dorsalmente os laterotergitos 8 .

Distribuição. Brasil (Mato Grosso e São Paulo).

Material-tipo. Holótipo ơ', BRASIL, Mato Grosso: Chapada [dos Guimarães], $15^{\circ} 26^{\prime} \mathrm{S}, 55^{\circ} 45^{\prime} \mathrm{W}, 1882-1884$, H. Smith col. (CMNH). Parátipos. \&, Chapada dos Guimarães, 09.IX.1978, J. Becker col. (MNRJ); +, São Paulo: Santo Antônio da Posse (Fazenda Dona Amélia), 14.X.1977, I. Sazima col. (UFRG).

Discussão. Edessa cerradensis sp. nov. caracterizase por apresentar o primeiro segmento do rostro tão longo quanto as búculas e pelas genitálias do macho e da fêmea: pigóforo com $1+1$ escavações profundas na parede ventral da taça genital; bordo ventral do pigóforo com recorte central em "u"; processos da taça genital sinuosos, castanhoescuros, brilhantes e lisos; décimo segmento sem sulcos e com a face posterior declivente com três carenas longitudinais, a do meio mais evidente; gonocoxitos 8 no mesmo plano que as demais placas genitais, margem posterior com uma projeção afilada pronunciada; gonapófises 9 invisíveis; gonocoxitos 9 sem carena.

\section{Edessa chapadensis sp. nov.} (Figs. 12, 24, 50, 57)

Etimologia. Epíteto alusivo à Chapada dos Guimarães, localidade-tipo dos exemplares.

Descrição. Comprimento 16,5-18; largura 9,4-10,06, corpo levemente ovalado (Fig. 12). Coloração geral verdeclara; face ventral verde-clara sem estrias negras. Cabeça finamente pontuada; jugas com pequenos sulcos transversais, arredondadas e curvadas ventralmente no ápice. Tubérculos anteníferos com dente vestigial; 
antenômeros 1 a 5 em ordem crescente de comprimento. Rostro atingindo a primeira bifurcação do processo do metasterno; primeiro segmento do rostro mais longo que as búculas; segundo segmento tão longo quanto o terceiro e quarto reunidos; búculas paralelas. Pronoto declivente, rugoso, pontuado, brilhante, com os ângulos ântero-laterais com um pequeno dente. Margens ânterolaterais retas, íntegras e levemente emarginadas. Ângulos umerais não-desenvolvidos. Cicatrizes do pronoto subcalosas e não-pontuadas. Escutelo brilhante, com ápice levemente acuminado e pontuação mais fina que o pronoto. Cório fosco; com pontuação mais fina e densa que o resto do corpo e veias sem diferença de coloração; margem costal do cório com pontuação clara igual à do pronoto. Membrana do hemiélitro castanho-clara, brilhante e transparente. Superfície ventral do pronoto com pontuação clara. Mesosterno pontuado, com uma carena mediana baixa que avança até as coxas anteriores. Processo metasternal mais longo que largo, achatado, liso e glabro; bifurcação anterior do processo metasternal divergente, com os ápices evanescentes, atingindo o terço posterior do mesosterno e acomodando o quarto e parcialmente o terceiro segmento do rostro. Área evaporatória rugosa, fosca e com a mesma cor da face ventral; peritrema ostiolar atingindo $3 / 5$ da largura da metapleura. Conexivo com a pontuação concolor, muito fina e densa. Ângulos póstero-laterais do conexivo e posteriores do sétimo segmento agudos. Face dorsal do abdome castanho-clara; superfície ventral com pontuação fina. Tricobótrios: um na mesma linha dos espiráculos e outro externo.

Genitália do macho (Fig. 24). Pigóforo retangular em vista dorsal; abertura dorso-posterior, ângulos póstero-laterais arredondados; superfície ventral com pontuações esparsas e um par de elevações próximas ao bordo ventral (Fig. 57); bordo ventral com recorte central em "v". Pigóforo com 1+1 escavações profundas na parede ventral da taça genital. Parâmeros com cabeça mais pé geniculados; cabeça distintamente afilada e direcionada para a região anterior; face ântero-lateral dos parâmeros escura com textura diferenciada e voltada para os processos da taça genital. Processos da taça genital achatados dorso-ventralmente, sinuosos, castanhoclaros, brilhantes e lisos, situados junto ao bordo dorsal do pigóforo. Décimo segmento cilíndrico, com pilosidade esparsa e sem sulcos; face posterior declivente, com três carenas longitudinais, a do meio mais pronunciada.

Genitália da fêmea (Fig. 50). Gonocoxitos 8 pontuados, decliventes, mais elevados que as demais placas genitais, margem posterior com uma projeção afilada pronunciada. Gonocoxitos 9 planos e destituídos de carena. Laterotergitos 8 com projeções afiladas bem pronunciadas e subiguais aos laterotergitos 9 . Laterotergitos 9 afilados, ultrapassando conspicuamente o bordo posterior da banda que une dorsalmente os laterotergitos 8 .

Distribuição. Brasil (Mato Grosso).

Material-tipo. Holótipo $\sigma^{7}$, BRASIL, Mato Grosso: Chapada dos Guimarães, 09.IX.1978, J. Becker col. (MNRJ). Parátipo + , Chapada [dos Guimarães], $15^{\circ} 26^{\prime} \mathrm{S}$ e $55^{\circ} 45^{\prime} \mathrm{W}, 1882$ 1884, H. Smith col. (CMNH).
Discussão. Edessa chapadensis sp. nov. se diferencia da espécie anterior por apresentar o primeiro segmento do rostro mais longo que as búculas, bordo ventral do pigóforo com recorte central em "v" e gonocoxitos 8 mais elevados que as demais placas genitais.

\section{Edessa luteovenulata sp. nov.}

(Figs. 13, 25, 51, 58)

Etimologia. Epíteto alusivo à coloração da venação do cório.

Descrição. Comprimento 13,1-14,0; largura 7,1-7,9, corpo ovalado (Fig. 13). Coloração geral verde-clara; cório castanho; pernas e antenas amareladas. Face ventral verde-clara com estrias descoloridas. Cabeça com a superfície superior não-pontuada. Jugas com pequenos sulcos transversais e sem pontuação, arredondadas e curvadas ventralmente no ápice. Tubérculos anteníferos com dente vestigial; primeiro antenômero menor que o segundo, segundo e terceiro subiguais, quarto maior que o terceiro e quinto maior que o quarto. Rostro atingindo a primeira bifurcação do processo do metasterno, com o primeiro segmento tão longo quanto as búculas; segundo segmento do rostro menor que o terceiro e quarto reunidos; búculas paralelas. Pronoto rugoso, pontuado, brilhante, com os ângulos ântero-laterais armados com um pequeno dente. Margens ântero-laterais retas, íntegras e levemente emarginadas. Ângulos umerais nãodesenvolvidos. Cicatrizes do pronoto subcalosas e nãopontuadas. Escutelo brilhante, com ápice levemente acuminado, com pontuação mais fina que o pronoto. Cório fosco, castanho, com pontuação mais fina e densa do que o resto do corpo; veias amareladas; margem costal do cório com pontuação grosseira. Membrana do hemiélitro brilhante, castanho-clara. Superfície ventral do pronoto rugosa e pontuada. Mesosterno pontuado, com uma carena mediana baixa que avança até as coxas anteriores. Processo metasternal mais longo que largo, achatado, liso e levemente piloso; bifurcação anterior do processo metasternal divergente, com os ápices evanescentes, atingindo o terço mediano do mesosterno e acomodando o quarto e parcialmente o terceiro segmento do rostro. Área evaporatória rugosa, fosca e com a mesma cor da face ventral; peritrema ostiolar atingindo $3 / 5$ da largura da metapleura. Conexivo com a pontuação concolor muito fina e densa. Ângulos póstero-laterais do conexivo e posteriores do sétimo segmento pouco desenvolvidos e agudos. Face dorsal do abdome castanho-escura; superfície ventral com pontuação muito fina e esparsa. Tricobótrios externos à linha dos espiráculos.

Genitália do macho (Fig. 25). Pigóforo retangular em vista dorsal; abertura dorso-posterior, ângulos póstero-laterais arredondados; superfície ventral (Fig. 58) com sulcos e elevações; bordo ventral com recorte central em "u" aberto. Pigóforo com 1+1 escavações pouco profundas na parede ventral da taça genital. Parâmeros com cabeça mais pé geniculados, sendo a cabeça voltada para a região anterior e a face ântero-lateral escura, com textura diferenciada e direcionada para o processo da taça genital. Processos da taça genital quadrangulares, bem visíveis, castanho-escuros, situados junto ao bordo 
dorsal do pigóforo. Décimo segmento cilíndrico, com um par de sulcos rasos recobertos por pêlos e a face posterior levemente truncada e sem carenas.

Genitália da fêmea (Fig. 51). Gonocoxitos 8 pontuados, no mesmo plano que as demais placas genitais, com uma área elevada iniciando junto ao bordo sutural e se estendendo em curva até próximo o bordo posterior; margem posterior em arco, com recorte na metade apical do bordo sutural; projeção afilada do bordo posterior ausente, deixando visíveis as gonapófises 9 . Gonocoxitos 9 planos, destituídos de carena. Laterotergitos 8 com projeções curtas, levemente mais longas que os laterotergitos 9. Laterotergitos $9 \mathrm{com}$ as extremidades arredondadas e subiguais ao bordo posterior da banda que une dorsalmente os laterotergitos 8 .

Distribuição. Brasil (Mato Grosso).

Material-tipo. Holótipo ơ, BRASIL, Mato Grosso: Chapada [dos Guimarães], $15^{\circ} 26^{\prime} \mathrm{S}, 55^{\circ} 45^{\prime} \mathrm{W}, 1882-1884, \mathrm{H}$. Smith col. (CMNH). Parátipo + , mesmos dados do holótipo $(\mathrm{CMNH})$

Discussão. Edessa luteovenulata sp. nov. diferencia-se por apresentar: cório castanho, fosco, com as veias de coloração amarelada e margem costal com pontuação grosseira da mesma cor que o cório; tricobótrios externos à linha dos espiráculos; processos da taça genital quadrangulares, castanho-escuros e bem visíveis; décimo segmento com um par de sulcos rasos recobertos por pêlos e a face posterior levemente truncada e sem carenas e gonapófises 9 visíveis.

\section{Edessa rufodorsata sp. nov.} (Figs. 14, 26, 38, 39, 52)

Etimologia. Epíteto alusivo à coloração avermelhada da face dorsal do abdome.

Descrição. Comprimento 13,7-14,6; largura 8,4-9,5; corpo ovalado (Fig. 14). Face dorsal verde; margens das jugas, margens ântero-laterais do pronoto e margem do terço anterior do cório branco-amareladas; conexivo avermelhado; face ventral, pernas e antenas alaranjadas; estrias castanhas nas áreas intersegmentares do abdome e posteriormente aos espiráculos. Jugas com pequenos sulcos transversais e pontuação abundante, arredondadas e curvadas ventralmente no ápice. Tubérculos anteníferos com dente reduzido; antenômeros 1 a 5 em ordem crescente de comprimento. Rostro atingindo a primeira bifurcação do processo do metasterno, com o primeiro segmento do mesmo comprimento que as búculas; segundo subigual ao terceiro e este maior que o quarto. Búculas paralelas e largas. Pronoto declivente, brilhante, pontuado, com os ângulos ântero-laterais armados com um pequeno dente. Margens ântero-laterais retas, íntegras e nãoemarginadas. Ângulos umerais não-desenvolvidos. Cicatrizes do pronoto subcalosas e não-pontuadas. Superfície ventral do pronoto com pontuação castanha. Escutelo densamente pontuado, brilhante; ápice levemente acuminado. Cório fosco, com pontuação densa e veias uniformes na tonalidade. Membrana do hemiélitro castanha. Mesosterno com carena mediana baixa que avança até as coxas anteriores. Processo metasternal mais longo que largo, achatado, liso e glabro; bifurcação anterior do processo metasternal divergente, com os ápices evanescentes, atingindo o terço posterior do mesosterno e acomodando parcialmente o quarto segmento do rostro. Área evaporatória rugosa, fosca e da mesma cor da face ventral; peritrema ostiolar atingindo $3 / 5$ da largura da metapleura. Pontuação do conexivo fina. Ângulos póstero-laterais do conexivo e posteriores do sétimo segmento não-desenvolvidos. Face dorsal do abdome avermelhada; superfície ventral não-pontuada e finamente estriada. Tricobótrios: um na linha dos espiráculos e outro externo.

Genitália do macho (Fig. 26). Pigóforo retangular em vista dorsal, com abertura dorso-posterior e ângulos póstero-laterais arredondados; superfície ventral, na metade posterior, com pontuações esparsas, sem sulcos e apresentando uma gibosidade central. Cabeça do parâmero com duas projeções, uma dirigida anteriormente, alongada, com ápice arredondado e uma posterior, retangular (Fig. 38). Face externa da cabeça do parâmero de textura diferenciada, apresentando uma elevação que se estende pela projeção anterior. Processo da taça genital retangular, achatado lateralmente, fendido medianamente, com as porções desencontradas em vista sagital; processo não encoberto pelo parâmero (Fig. 39). Décimo segmento com margem posterior projetada, sulcada e recoberta por pêlos; face posterior truncada e sem carenas.

Genitália da fêmea (Fig. 52). Gonocoxitos 8 pilosos, pontuados e em plano diferente das demais placas genitais. Bordo posterior do gonocoxito 8 formando um arco levemente sinuoso. Gonocoxitos 9 pilosos, trapezoidais, convexos e sem carena mediana. Laterotergitos 8 pilosos, pontuados, com projeções pouco desenvolvidas e subiguais aos laterotergitos 9; laterotergitos 9 pilosos, pontuados, com as extremidades arredondadas e ultrapassando ligeiramente a banda que une dorsalmente os laterotergitos 8. Décimo segmento pouco convexo e sem estrias.

Distribuição. Brasil (Mato Grosso e São Paulo) e Argentina (Salta e Tucumán).

Material-tipo: Holótipo $\sigma^{2}$, ARGENTINA, Tucumán: Los Nogales (Dpto. Capital), 28.I.1947, Ares col. (MCNZ). Parátipos. o', BRASIL, Mato Grosso: Barra do Tapirapé, 14.XII.1964, B Malkin col. (MZSP); + , São Paulo: Limeira, 01.XII.1953 (MCNZ); ARGENTINA, ơ,, , Tucumán (MACN); , Salta: Rio Bermejo, IV.1914 (CMNH).

Discussão. Edessa rufodorsata sp. nov. é uma espécie muito semelhante a E. rufomarginata, diferenciando-se desta pelas seguintes características: primeiro segmento do rostro do mesmo comprimento das búculas, face dorsal do abdome avermelhada e processo da taça genital com as porções desencontradas em vista sagital.

\section{Edessa virididorsata sp. nov. (Figs. 15, 27, 40, 41, 53)}

Etimologia. Epíteto alusivo à coloração dorsal verde do abdome. 
Descrição. Comprimento 13,4-17,3; largura 8,4-10,3, corpo ovalado (Fig. 15). Face dorsal verde-oliva, com pontuação escura, face ventral, pernas e antenas alaranjadas; estrias negras nas áreas intersegmentares do tórax e abdome, nas pseudo-suturas e posteriormente aos espiráculos. Jugas arredondadas e curvadas ventralmente no ápice, pontuadas e com pequenos sulcos transversais. Tubérculos anteníferos com dente reduzido; antenômeros em ordem crescente de comprimento. Rostro atingindo a primeira bifurcação do processo do metasterno, com o primeiro segmento mais longo que as búculas; segundo segmento maior do que o terceiro e este maior que o quarto. Búculas paralelas, inclinadas e largas. Pronoto declivente e com as cicatrizes subcalosas não-pontuadas. Ângulos ântero-laterais com um pequeno dente inconspícuo. Margens ântero-laterais retas, íntegras e emarginadas. Ângulos umerais nãodesenvolvidos. Superfície ventral com pontuação clara. Escutelo com ápice arredondado. Cório com veias sem diferença de coloração. Membrana do hemiélitro
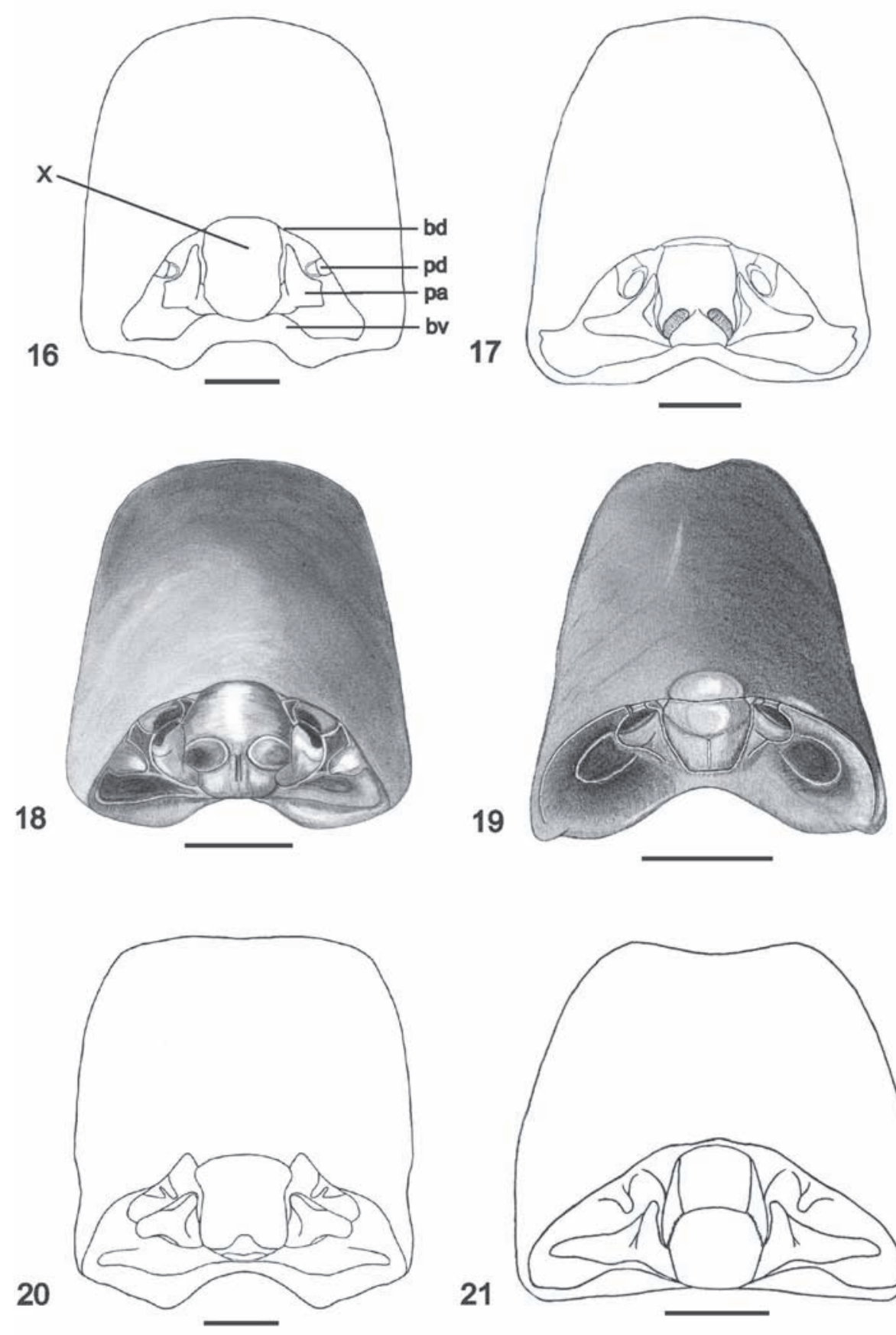

21

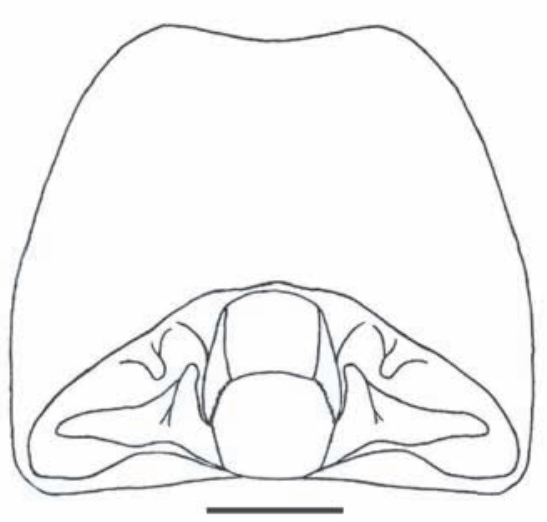

Figs. 16-21. Pigóforo, vista dorso-posterior: 16, Edessa abdominalis Erichson, 1848; 17, Edessa corallipes Erichson, 1848; 18, Edessa aulacosterna Stål, 1872; 19, Edessa ovalis Stål, 1872; 20, Edessa nigropunctata Berg, 1884; 21, Edessa brasiliensis sp. nov. (holótipo) (bd, bordo dorsal; bv, bordo ventral; pa, parâmero; pd, processo da taça genital; X, $10^{\circ}$ segmento abdominal). Escalas $=1 \mathrm{~mm}$. 
brilhante, castanho-escura a negra. Mesosterno com carena mediana. Processo metasternal mais longo que largo e piloso nas margens; bifurcação anterior do processo metasternal divergente e com os ápices evanescentes, atingindo o terço posterior do mesosterno, acomodando o quarto segmento do rostro e parcialmente o terceiro. Área evaporatória rugosa, fosca, com a mesma cor da face ventral; peritrema ostiolar atingindo $4 / 5$ da largura da metapleura. Abdome com conexivo alaranjado e pontuação fina. Ângulos póstero-laterais do conexivo e posteriores do sétimo segmento não-desenvolvidos. Face dorsal do abdome verde; superfície ventral lisa. Tricobótrios: um na linha do espiráculo e o outro externo.

Genitália do macho (Fig. 27). Pigóforo retangular em vista dorsal, com abertura dorso-posterior, pilosidade densa na taça genital, principalmente junto ao bordo

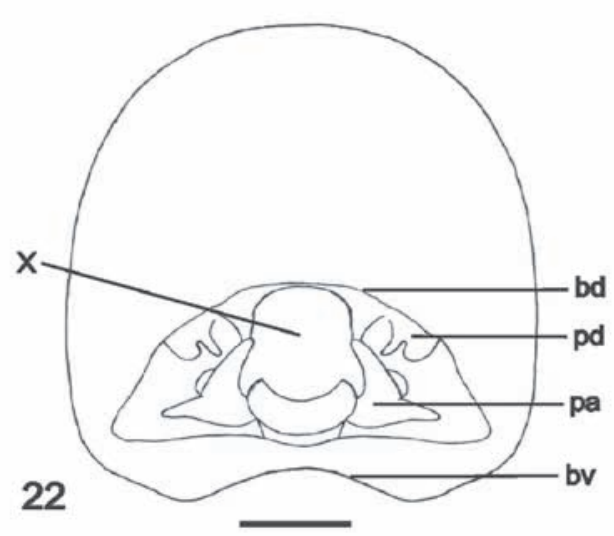

23
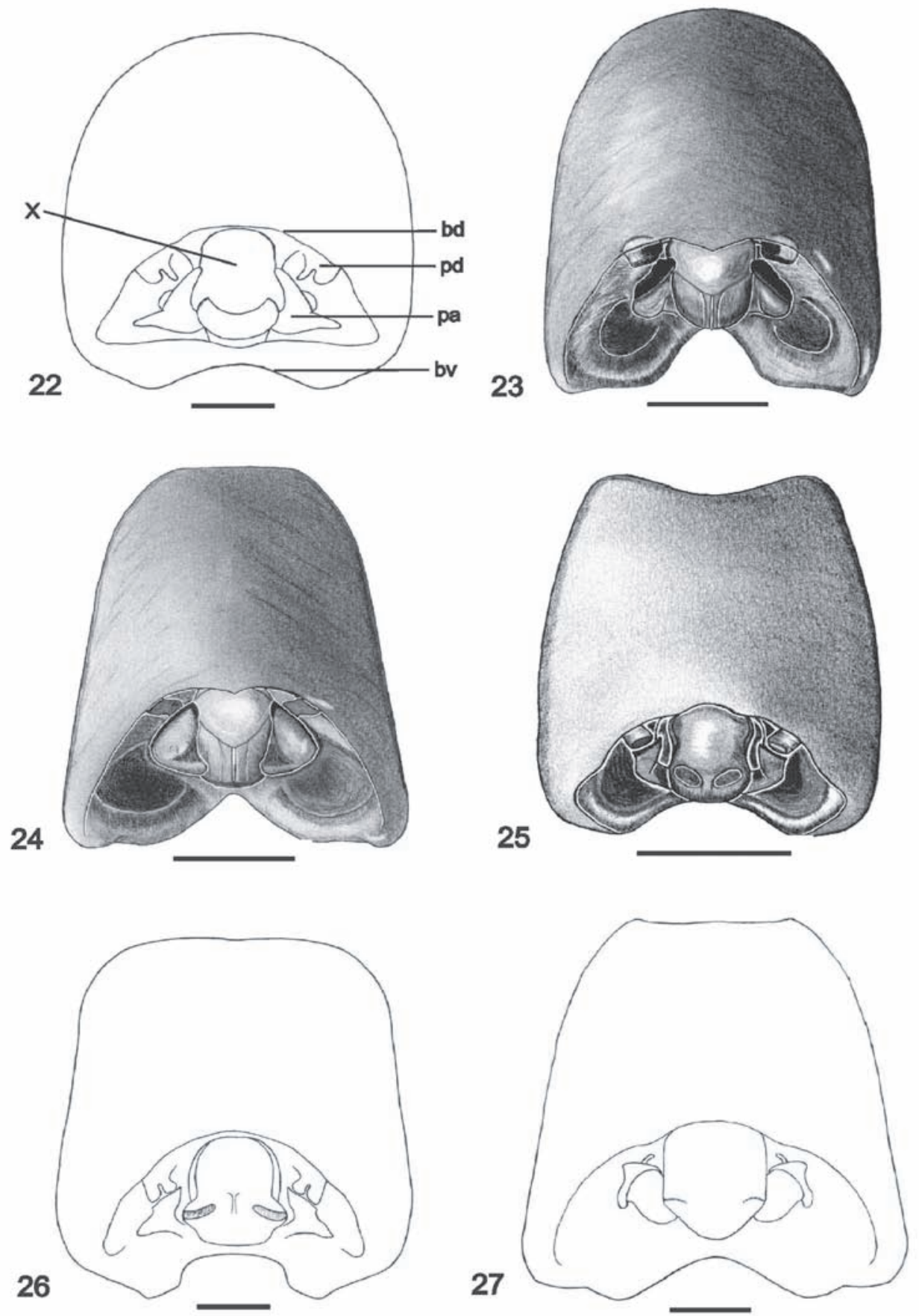

Figs. 22-27. Pigóforo, vista dorso-posterior (holótipos): 22, Edessa castaneolineata sp. nov.; 23, Edessa cerradensis sp. nov.; 24, Edessa chapadensis sp. nov.; 25, Edessa luteovenulata sp. nov.; 26, Edessa rufodorsata sp. nov.; 27, Edessa virididorsata sp. nov. (bd, bordo dorsal; bv, bordo ventral; pa, parâmero; pd, processo da taça genital; X, $10^{\circ}$ segmento abdominal). Escalas $=1 \mathrm{~mm}$. 
dorsal, e ângulos póstero-laterais arredondados; superfície ventral com pontuação esparsa na metade posterior. Cabeça do parâmero com duas projeções muito reduzidas: uma anterior afilada e outra posterior retangular (Fig. 40); face externa escura, com textura diferenciada e uma elevação central estreita e sinuosa; face interna lisa. Processo da taça genital reduzido, achatado dorsoventralmente, formado apenas por uma aba do tegumento
(Fig. 41). Décimo segmento cilíndrico, com margem posterior não-projetada e sulcos cobertos por pêlos; face posterior declivente, com pequenos sulcos e uma carena central baixa.

Genitália da fêmea (Fig. 53). Gonocoxitos 8 pilosos, pontuados, em um plano mais alto que o das demais placas genitais e com uma gibosidade central. Bordo posterior do gonocoxito 8 em ogiva. Gonocoxitos 9
28

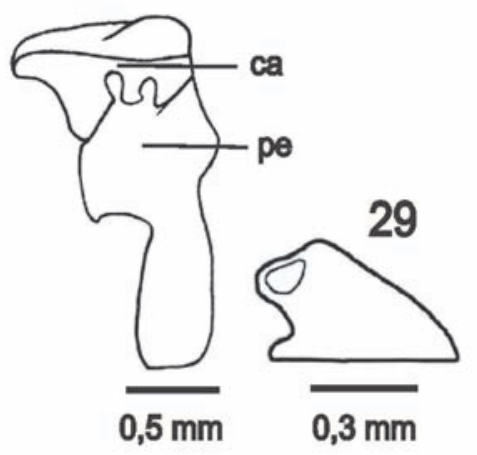

30

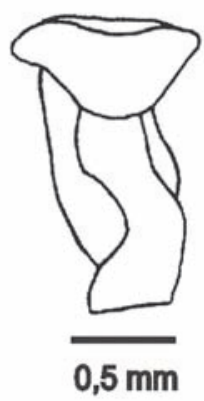

32

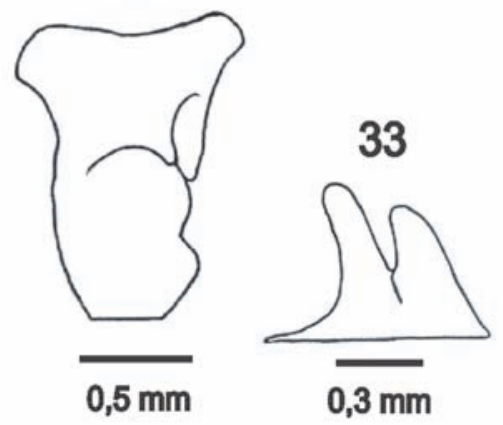

Figs. 28-33. Parâmero e processo da taça genital: 28, 29, Edessa abdominalis Erichson, 1848; 30, 31, Edessa corallipes Erichson, 1848; 32, 33, Edessa nigropunctata Berg, 1884 (ca, cabeça; pe, pé).
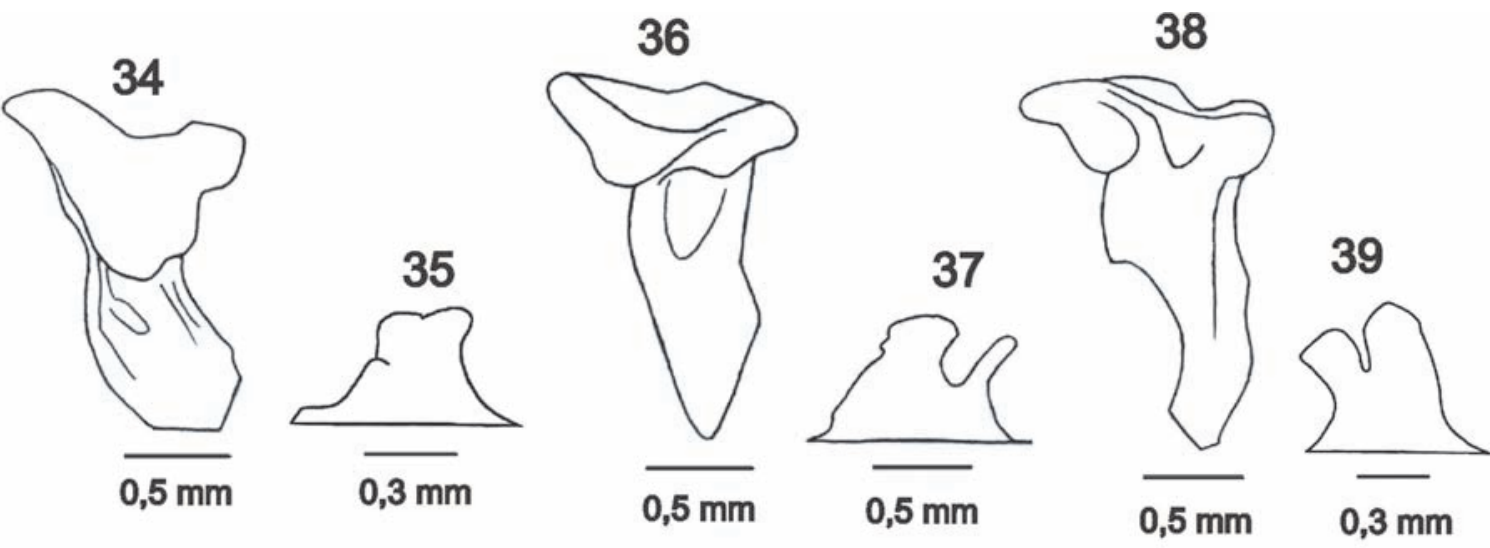

40

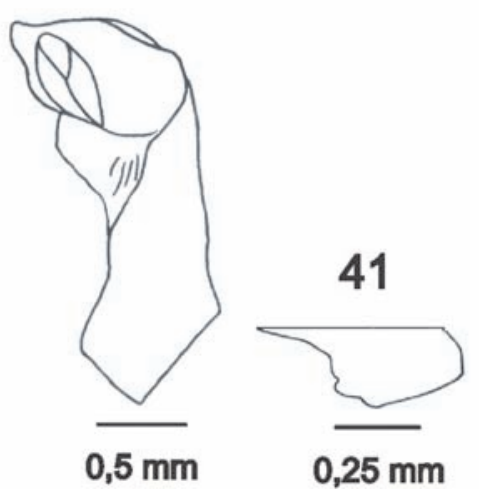

Figs. 34-41. Parâmero e processo da taça genital (holótipos): 34, 35, Edessa brasiliensis sp. nov.; 36, 37, Edessa castaneolineata sp. nov.; 38, 39, Edessa rufodorsata sp. nov.; 40, 41, Edessa viridisdorsata sp. nov.. 
pilosos, pontuados, trapezoidais, convexos e com carena mediana. Laterotergitos 8 pontuados, com as projeções curtas ultrapassando levemente os laterotergitos 9 . Laterotergitos 9 arredondados, não-pontuados e subiguais ao bordo posterior da banda que une dorsalmente os laterotergitos 8. Décimo segmento convexo e estriado.

Distribuição. Venezuela, Guiana, Suriname, Guiana Francesa, Brasil, Paraguai e Argentina.

Material-tipo: Holótipo O', BRASIL, Distrito Federal:
Brasília, 06.IX.1979, C. Marconi col. (MCNZ). Parátipos: COLÔMBIA, Magdalena: Hacienda Cacagualito, 3 \&, ở, V.1999 (CMNH); VENEZUELA, Caracas: Caracas, $80^{*}, 9$, Gollner col., 3738, (ZMHB); 2 o', 2 क (UFRG); E. van Bruyssel col., $20^{7}$ (IRSB); Aragua: Rancho Grande, O', ᄋ, 17.IX.1951, F. Yepez col. (UFRG), \& (MIZA); O’, 19.IV.1949 (MIZA); O', 28.VIII.1949, F. Yepez \& P. Fenives col. (MIZA); Villa de Cura, 2 ㅇ, 1923, Mayeul Grisol col. (MNHN); GUIANA, Schomburgk, 2 o', 322 (ZMHB); SURINAME, 2 O', 664 e 1048, P. van Doesburg col. (RMNH); GUIANA FRANCESA, ơ , +, 1899, Coll. Bar, R. Oberthur col. (MNHN); BRASIL, Pará: Oriximiná, + , IV-1978, A. C. Domingos col. (MPEG); Rondônia: Porto Velho, 4 q, XII.1978, A.C. Domingos (RMNH); Mato Grosso: Serra do Roncador (1250'S
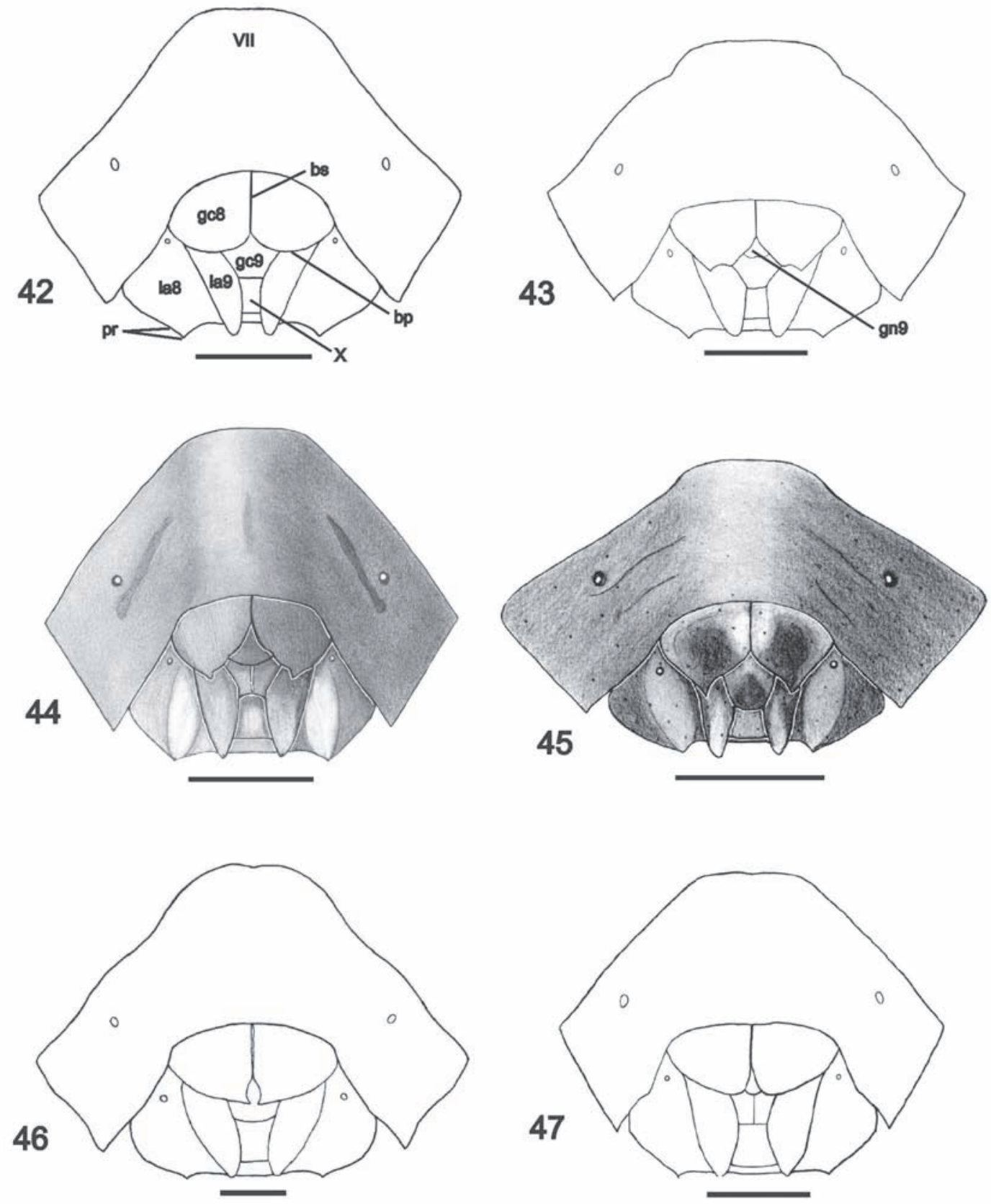

Figs. 42-47. Genitália feminina, vista ventral: 42, Edessa abdominalis Erichson, 1848; 43, Edessa corallipes Erichson, 1848; 44, Edessa aulacosterna Stål, 1872; 45, Edessa ovalis Stål, 1872; 46, Edessa nigropunctata Berg, 1884; 47, Edessa brasiliensis sp. nov. (bp, bordo posterior; bs, bordo sutural; gc8, gonocoxito 8; gc9, gonocoxito 9; gn9, gonapófise 9; la8, laterotergito 8; la9, laterotergito 9; pr, projeção do laterotergito 8 ; VII, $7^{\circ}$ segmento abdominal; X, $10^{\circ}$ segmento abdominal). Escalas $=2 \mathrm{~mm}$. 
$\left.51^{\circ} 45^{\prime} \mathrm{W}\right), 2 \sigma^{`}$, B. Freeman col. (BMNH); Chapada dos Guimarães, 2 ơ, 2966 (CMNH); Cuiabá, 2 đ’, 4 ㅇ, 2-5.II.1980, D. Thomas col. (DTC); 2 q (MZSP); Utiariti (Rio Papagaio), ở, †, 21-31.X.1966, Lenko \& Pereira col. (MZSP); Goiás: Corumbá de Goiás, đ’, 4.II.1962, J. \& B. Bechyné col. (MPEG); Distrito Federal: Planaltina (Embrapa Cerrados), ơ, 18.VI.1986 (MCNZ); Minas Gerais: Uberaba, $\sigma^{7}, \rho_{\text {, }}$ E. le Moult col. (RMNH); Rio de Janeiro: Itatiaia (Fazenda Penedo), 2 o', 2 \%, 15-II-1942, Wygodzinsky col. (MNRJ); 2 శ, 2 † (MPEG); Nova Friburgo, ơ (IRSB); São Paulo: São Carlos (Fazenda Canchim), ơ, 23.X.1993, N. Perioto col. (MZSP); PARAGUAI, 2 \&, 2 \%, 1900, Gosset col. (MNHN); Carumbé, +, 01.II - 08.III.1966, R. Golbach col. (IMLA). ARGENTINA, Salta: Seclantás, +, 27.I.1950, Monrós-Willink col. (IMLA); Misiones: Loreto, Ơ, 2 \&, VIII.1955, F. H. Waltz

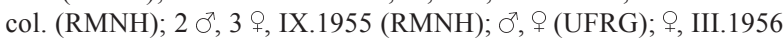
(RMNH); ठౌ', XII.1956 (RMNH).

Discussão. Edessa virididorsata sp. nov. caracteriza-se por apresentar face dorsal do abdome verde, pilosidade densa na taça genital, principalmente junto ao bordo dorsal, cabeça do parâmero com duas projeções muito reduzidas e processo da taça genital reduzido, achatado dorso-ventralmente, formado apenas por uma aba do tegumento.
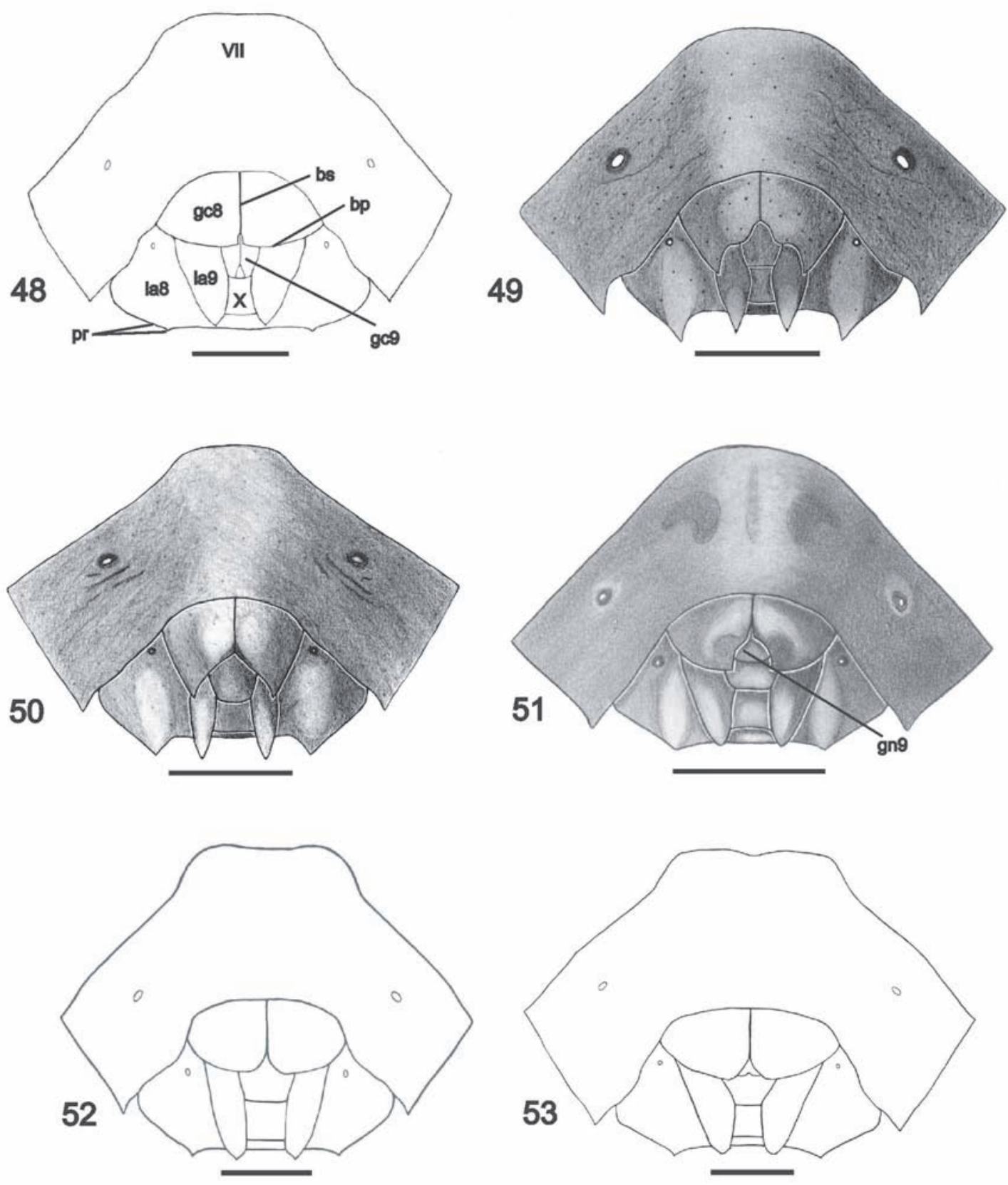

Figs. 48-53. Genitália da fêmea, vista ventral: 48, Edessa castaneolineata sp. nov.; 49, Edessa cerradensis sp. nov.; 50, Edessa chapadensis sp. nov.; 51, Edessa luteovenulata sp. nov.; 52, Edessa rufodorsata sp. nov.; 53, Edessa virididorsata sp. nov. (bp, bordo posterior; bs, bordo sutural; gc8, gonocoxito 8; gc9, gonocoxito 9; gn9, gonapófise 9; la8, laterotergito 8; la9, laterotergito 9; pr, projeção do laterotergito 8 ; VII, $7^{\circ}$ segmento abdominal; X, $10^{\circ}$ segmento abdominal). Escalas $=2 \mathrm{~mm}$. 


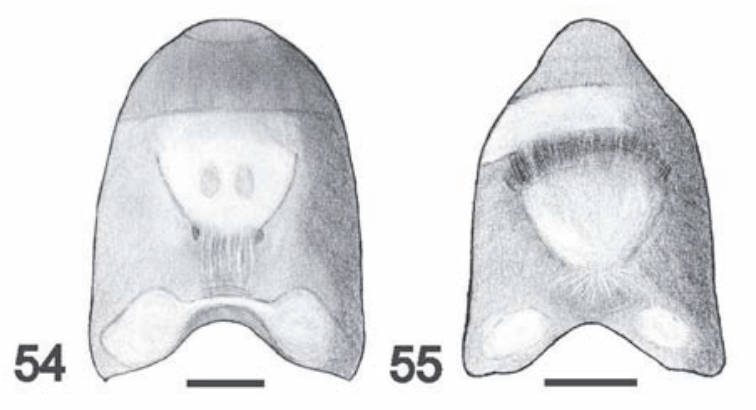

56
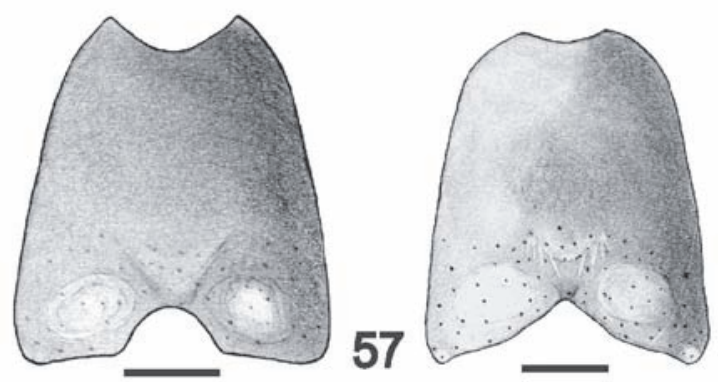

58

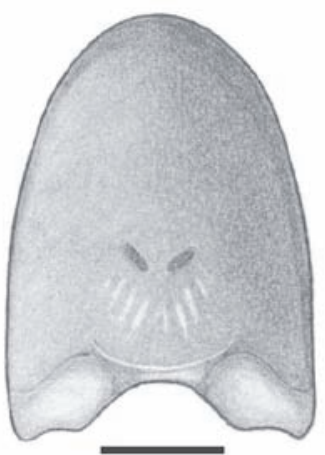

Figs. 54-58. Pigóforo, vista ventral: 54, Edessa aulacosterna Stål, 1872; 55, Edessa ovalis Stål, 1872; 56, Edessa cerradensis sp. nov.; 57, Edessa chapadensis sp. nov.; 58, Edessa luteovenulata sp. nov. Escalas $=2 \mathrm{~mm}$.
Agradecimentos. Ao Dr. A. O. Bachmann, Museo Argentino de Ciencias Naturales "Bernardino Rivadavia" (MACN), pelo empréstimo dos exemplares. Aos curadores Dr. J. Deckert (ZMHB), Dr. H. Zettel (NHMV) e Dr. B. Viklund (NHRM), por permitir o exame dos tipos.

\section{REFERÊNCIAS BIBLIOGRÁFICAS}

Berg, C. 1884. Addenda et emendanda ad Hemiptera Argentina. Anales de la Sociedad Científica Argentina 17:7-213.

Dallas, W. L. 1851. List of the specimens of Hemipterorus insects in the collection of the British Museum. Part I. London, The Trustees. 390p.

Distant, W. L. 1880-1883. Biologia Centrali-Americana. Rhynchota. Hemiptera-Heteroptera. London, Godman \& Salvin. v.1, 462p.

Dupuis, C. 1970. Heteroptera. In: Tuxen, S. L. ed. Taxonomist's glossary of genitalia of insects. Copenhagen, Munskgaard. p. 190-208.

Erichson, W. F. 1848. Insecten. In: Schomburg, K. R. ed. Reisen in British Guiana. Leipzig, Von J. J. Weber. p.553-617.

FABricius, I. C. 1803. Systema rhyngotorum secundum ordines, genera, species, adjectis synonymis, locis, observationibus, descriptionibus. Brunsvigae, Carolum Reichard. 314p.

Fernandes, J. A. M. \& Doesburg, P. H. Van. 2000a. The E dolichocera-group of Edessa Fabricius, 1803 (Heteroptera: Pentatomidae: Edessinae). Zoologische Mededelingen 73(20):305-315.

. 2000b. The E. beckeri-group of Edessa Fabricius, 1803 (Heteroptera: Pentatomidae: Edessinae). Zoologische Mededelingen 74(7):143-150.

2000c. The E. cervus-group of Edessa Fabricius, 1803 (Heteroptera: Pentatomidae: Edessinae). Zoologische Mededelingen 74(8):151-165.

Fernandes, J. A. M., Doesburg, P. H. Van \& Greve, C. 2001. The E. collaris-group of Edessa Fabricius, 1803 (Heteroptera: Pentatomidae: Edessinae). Zoologische Mededelingen 75(15):239-250.

Kirkaldy, G. W. 1909. Catalogue of Hemiptera (Heteroptera). 1 Cimicidae. Berlin, Felix L. Dames. 392p.

Lethierry, L. \& Severin, G. 1893. Catalogue Général des Hémiptères. Tome I. Hétéroptères Pentatomidae. Bruxelas, F. Hayez. 286p.

Silva, E. J. E.; Fernandes, J. A. M. \& Grazia, J. 2004. Variações morfológicas em Edessa rufomarginata e revalidação de $E$. albomarginata e E. marginalis (Heteroptera, Pentatomidae, Edessinae). Iheringia, Série Zoologia 94(3):261-268.

STÅL, C. 1872. Enumeratio Hemipterorum. Bildrag till em förteckning öfver alla hittilis Hemiptera, jemte systematiska meddelanden. 2. Bihang till Kongliga Svenska Vetenskaps-Akademiens Handlingar 10(4):1-159.

Walker, F. 1867. Catalogue of the specimens of Heteropterous-Hemiptera in the collection of the British Museum. London, British Museum. Parts 1-3, 599p.

Recebido em junho de 2005. Aceito em junho de 2006. ISSN 0073-4721

Artigo disponível em: www.scielo.br/isz 